\title{
Article
}

\section{GIVE as a PUT verb in German - A case of German-Czech language contact?}

\author{
Alexandra N. Lenz ${ }^{1,2}$, Fabian Fleißner ${ }^{2}$, Agnes $\mathrm{Kim}^{3}$ and Stefan Michael Newerkla ${ }^{3}$ \\ ${ }^{1}$ Department of German Studies, University of Vienna, ${ }^{2}$ Austrian Centre for Digital Humanities and Cultural Heritage (ACDH-CH), Austrian Academy of Sciences \\ and ${ }^{3}$ Department of Slavonic Studies, University of Vienna
}

\begin{abstract}
This contribution focuses on the use of geben 'give' as a PUT verb in Upper German dialects in Austria from a historical and a recent perspective. On the basis of comprehensive historical and contemporary data from German varieties and Slavic languages our analyses provide evidence for the central hypothesis that this phenomenon traces back to language contact with Czech as already suggested by various scholars in the 19th century. This assumption is also supported by the fact that Czech dát 'give' in PUT function has been accounted for since the Old Czech period as well as by its high frequency in both formal and informal Czech written texts. Moreover, our data analyses show that geben 'give' as a PUT verb has been and is still areally distributed along and spreading from the contact area of Czech and Upper German varieties.
\end{abstract}

Keywords: caused motion construction; PUT verbs; German; Slavic languages; language contact; language variation

(Received 23 April 2019; revised 18 February 2020; accepted 20 February 2020; First published online 22 January 2021)

\section{Introduction}

It is well known that basic GIVE $^{1}$ verbs are a fruitful source for various grammaticalization and lexicalization pathways in the languages of the world (for an overview cf. Newman, 1996; Heine \& Kuteva, 2002). Our contribution discusses a linguistic phenomenon, which has previously been neglected in research; the semantic development of a basic GIVE verb towards a PUT verb. As our analyses show, German geben 'give' is increasingly used in so called "caused motion constructions," i.e., constructions with the semantics "X CAUSES Y TO MOVE Z" (Goldberg, 1995). In these constructions, German geben 'give' - at least in some areas and varietiescan refer to object movements with an inanimate target (cf. [1]) and even with an inanimate source (cf. [2]).

(1) Target-oriented object movement (Ammon, Bickel \& Lenz, 2016: s.v. geben)

eine Parkscheibe hinter die Windschutzscheibe geben

a parking disc.Acc behind the windshield.Acc give.INF

'put (lit.: give) a parking disc behind the windshield'

(2) Source-oriented object movement (http://tortenzwerg.at/7-days-oflove-kekse-mit-glasinneren/)

$\begin{array}{lll}\text { Teig } & \text { aus der Schüssel } & \text { geben } \\ \text { dough.ACC } & \text { out of the bowl.DAT } & \text { give.INF } \\ \text { 'take (lit.: give) the dough out of the bowl' } & \end{array}$

Current studies show that geben 'give' as a German PUT verb is frequently used, especially in the Eastern Upper German language

Author for correspondence: Alexandra N. Lenz, Email: alexandra.lenz@univie.ac.at Cite this article: Lenz AN, Fleißner F, Kim A, and Newerkla SM. (2020) GIVE as a PUT verb in German - A case of German-Czech language contact? Journal of Linguistic Geography 8: 67-81, https://doi.org/10.1017/jlg.2020.6 area (cf. Ammon, Bickel \& Lenz, 2016:265). This language area covers South East Germany (mainly the federal state of Bavaria), large parts of Austria, and South Tyrol in Northern Italy (cf. Map 2 in section 4.1.3). Considering this geographical concentration at the South Eastern borders of the German-speaking language areas, this article investigates to what extent the emergence of geben 'give' as a PUT verb is due to language contact between German and Czech. Researchers in the field of language contact suggested a similar hypothesis already in the 19th century (cf. section 3.2); however, their observations have never been examined systematically or empirically. This article presents evidence supporting the hypothesis by analyzing two sources. First, an examination of the results from the extensive "Wenker" questionnaire survey conducted between 1876 and 1933 allows for insights into the dialect geography of the contemporary German-speaking area at the end of the 19th and the beginning of the 20th century. Second, a comparison of these results with those from a recent 2016 dialect survey indicates that geben 'give' as a PUT verb continues to be frequently used today and that its use has been spreading from the contact area of German (more specifically: Eastern Upper German) and Slavic languages to further neighboring regions.

While section 2 focuses on categories of movement and their verbalization (mainly in German), section 3 summarizes current research on geben 'give' as a placement verb in German and presents corpus-based results on PUT verbs in Slavic languages. It also discusses the language contact hypothesis according to which geben 'put' can be considered a "Czechism" (Bohemismus, cf. Nekula \& Večerka, 2017). Section 4 presents our own analyses based on dialect data from the 19th to the 21 st century, which for the first time provide empirical evidence for the language contact hypothesis. Section 5 gives a comprehensive summary of the above. 


\section{A taxonomy of object movements and their (German) terms}

In a taxonomy of movements (cf. Figure 1), we can differentiate object movements as acts of externally caused movement from subject movements, in which the agent (by) himself is in motion (e.g., acts of COME and GO). ${ }^{2}$ In case of a target-oriented object movement (i.e., PUT action), the object moves (from an implicit or explicit starting position) towards a GOAL (cf. [1] above). In case of a source-oriented object movement (i.e., TAKE action), the focus lies on the movement away from a specific sourCE (cf. [2] above). As indicated by Figure 1, acts of object movement are strongly connected to acts of transfer, in which objects are also moved between two entities. However, while in the case of acts of transfer (i.e., actions of GIVE, GET and TAKE) an object is moved between two animate entities (OLD and NEW POSSESSOR), object movements are characterized by the inanimate nature of SOURCE and GOAL (cf. Lenz, 2013). However, both types of movement (placement versus transfer) comprise the semantic aspect of a change of state (BECOME), which means a change of location $\left(\mathrm{BEC}\left(\mathrm{BE}_{\mathrm{LOC}}\right)\right)$ and a change in HAVE-relation (BEC(HAVE)), respectively. ${ }^{3}$

Within the semantic network of concepts of object movements, GIVE, GET, TAKE and PUT can be categorized as basic categories in terms of prototype semantics. ${ }^{4}$ Basic categories are characterized through specific aspects and qualities such as their major sociocultural significance, their inclusivity as well as early acquisition and formal irregularities of their basic level terms (cf. Lenz, 2017; Newman, 2005). Basic level terms, with which it is possible to refer to basic categories of object movements, are the verbs give, get, take und put in English. While give and get function as basic verbs of transfer, put acts as a basic verb for 'putting events', which according to Narasimhan et al. (2012:10) can be described as follows: "deliberately placing an object somewhere under manual control." The classification of take is less straightforward (cf. Figure 1). Take can function as basic verb for acts of transfer (to take something [away] from someone) or it can refer to source-oriented object movements (to take something [away] from somewhere).

While there is a basic verb for target-oriented object movements in English, i.e., $p u t,{ }^{5}$ this lexical-semantic position in the language system is missing in German (at least in the German standard language). For the verbalization of PUT actions, the German standard language exclusively offers "specifying verbs," which refer to movements of a subordinated category. Lexical-semantic determining factors influencing the selection of a concrete specifying verb for target-oriented placements include the shape of the moved object (e.g., round versus square), its consistency (e.g., liquid or solid) and the position of the object in its new place. The most frequent specifying verbs in German are stellen ('put'/'cause to stand'), setzen ('put'/'cause to sit'), and legen ('put'/'cause to lie'), which are-as the only specifying PUT verbs-ranked among the 100 most frequent verbs in frequency dictionaries (cf. Jones \& Tschirner, 2006: stellen [39th position]; setzen [47th position]; legen [65th position]). All three verbs prototypically refer to the positioning of a solid object. Furthermore, even "if something that is not solid is understood to be in a container, it can be used with these verbs" (Fagan, 1991:137). Usage of either of the three verbs is strongly dependent on the object's final orientation: "A figure (such as a cup or a book), which ends up in its canonical upright position, is usually referred to with stellen 'to stand"' (Berthele, 2012:151; cf. also Leisi, 1961:65; cf. [3-5] below). However, if the object is put against its canonical upright position, i.e., for example on its back, legen 'cause to lie' is the prototypical verb for the object movement (cf. [6]

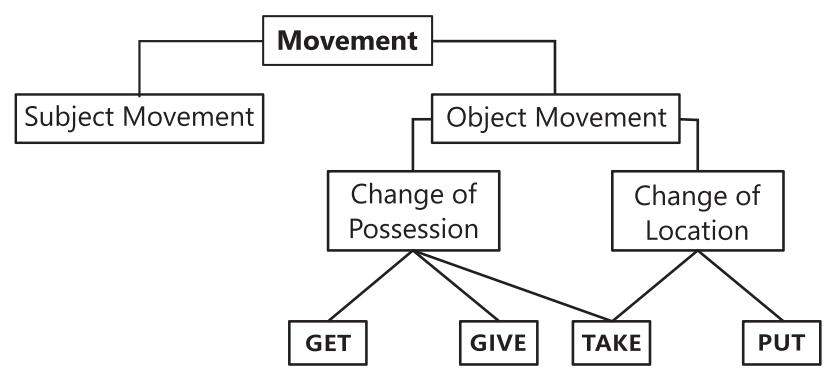

Figure 1. Taxonomy of MOVE actions (considerably simplified): Basic categories as well as superior and subordinate categories

below; for exceptions cf. Fagan, 1991). Setzen 'cause to sit', on the other hand, implies that the agent brings the object into a sitting position (cf. [7] below). Fagan (1991:142) explains the difference as:

the choice of verb is determined more by the location of the object than by its physical characteristics. For example, sitzen ['sit'; authors] and setzen ['put'/'cause to sit'; authors] are used to express that an object is located or placed on some elevated position, that it perches or is made to perch somewhere.

in den Schrank stellen

the blanket.Acc into the cupboard.Acc cause to stand.INF

'to put (lit.: cause to stand) the blanket into the cupboard'

(4) die Kanne in den Schrank stellen ${ }^{6}$

the pot.ACC into the cupboard.ACC cause to stand.INF

'to put (lit.: cause to stand) the pot into the cupboard'

(5) das Buch ins Regal stellen ${ }^{7}$

the book.ACC into.DEF.ART shelf.ACC cause to stand.INF

'to put (lit.: cause to stand) the book into the shelf'

(6) das Buch in den Koffer legen ${ }^{8}$

the book.Acc into the suitcase.Acc cause to lie.INF

'to put (lit.: cause to lie) the book into the suitcase'

(7) den Hut auf den Kopf setzen ${ }^{9}$

the hat.AcC onto the head.Acc cause to sit.INF

'to put (lit.: cause to sit) the hat on the head'

However, if the object is placed-with more or less exertioninto a narrow and tight container, which encloses its shape tightly, the verbs stecken 'push/stuck' and stopfen 'push/stuff are used in Standard German, in which stopfen is used for flexible materials like cloth and fabric.

(8) das Tuch

in das Loch

stopfen $^{10}$

the cloth.acc

into the hole.Acc

stuff.INF

'to put (push/stuff) the cloth into the hole'

(9) das Messer

in die Tasche

stecken $^{11}$

the knife.Acc into the bag.Acc

stick.INF

'to put (push/stick) a knife into the bag'

In case of non-solid objects, different specifying verbs are used in Standard German to refer to PUT actions: schütten and gießen 'pour' describe acts, in which the agent causes liquid to flow into a new container (cf. [10-11]). It is the intensity and the level of energy necessary to perform the act that differentiates between the more intense and faster act of schütten 'pour' and the more careful and slower act of gießen 'pour'. 
(10) Wasser

$$
\text { in die Wanne }
$$

water.AcC

into the tub.Acc

schütten $^{12}$

'to pour water into the tub'

(11) Wasser

$$
\text { auf die Blumen }
$$

gießen ${ }^{13}$

water.ACC

onto the flowers.ACC

pour.INF

'to water the flowers (lit.: to pour water onto the flowers)'

These specifying verbs are a selection of those frequently used in Standard German in order to express basic acts of placement. Note that the verbalization of acts of placement generally-not only in German, but in all languages of the world - underlies (further) complex decisive factors. However, due to the length and specific aims of this paper, these factors will not and cannot be elaborated on in more detail.

\section{GIVE as a PUT verb in German and Czech}

\subsection{Geben as a PUT verb in German? Lexicographical traces}

Up until now, research exclusively focused on Standard German, a variety that is regarded PUT-less at least from the perspective of the norm in Germany. However, if we consider non-standard varieties of German, we find potential candidates for basic PUT verbs. The verb tun 'do' can be presented as an example of this. It can be found in almost every dialect and regiolect of German and according to the Duden (2015) dictionary, it can at least colloquially comprise the following meanings:

(ugs.) irgendwohin bringen, befördern, setzen, stellen, legen: tu es an seinen Platz, in den Müll, in den Schrank; Salz an, in die Suppe t., das Geld tue ich auf die Bank; den Kleinen tun wir zur Oma (geben wir in ihre Obhut); sie taten (ugs.; schickten) die Tochter aufs Gymnasium. (Duden 2015: s.v. tun)

(colloq.) to bring somewhere, to transport, cause to stand [stellen], cause to sit [setzen], cause to lie [legen]: put [lit. do] it in its place, in the garbage, in the cabinet; put [lit. do] salt on, in the soup; I put [lit. do] the money in the bank; we will entrust [lit. do] the little one to grandma (entrust him to her care); they sent [lit. did] (colloq.) their daughter to high school. (own translation)

A glance into etymological dictionaries reveals that the verb tun 'do' in Old High German primarily had the semantic meaning of setzen 'cause to sit', stellen 'cause to stand' or legen 'cause to lie', whereas today, it functions as a generalized placement verb for all kinds of target-oriented PUT actions, also for the acts of streuen 'sprinkle' and stopfen 'stuff, as shown in (12) and (13):

(12) Salz

salt.ACC

in die Suppe

tun

'to put (lit.: do) salt into the soup'

do.INF

(13) Wäsche

in die Maschine

tun

laundry.ACC

into the machine.ACC

do.INF

'to put (lit.: do) laundry into the machine'

Another PUT verb in German is the verb geben 'give', which according to the Duden (2015) occurs with PUT semantics in Austria or "regionally" and which is interestingly often translated as tun 'do' in the dictionary article:

a) (österr., sonst landsch.) irgendwohin tun: Zucker an/über die Mehlspeise g.; eine Decke auf den Tisch g.; b) (Ballspiele) abgeben, weitergeben, spielen: den Ball in die Mitte g. (Duden 2015: s.v. geben)

a) (Austrian, otherwise regional) to put (lit.: do) somewhere: give sugar on/ all over the pastries; give a tablecloth on the table; b) (ball games) give up (pass), give over (pass on), play: give the ball to the middle [pass/take the ball to the centre]. (own translation)

A more concrete statement regarding how the verb geben 'give' as a PUT verb is diatopically and diastratically distributed is not provided. However, to answer this question we can consult the Variantenwörterbuch des Deutschen 'Dictionary of Variants in German' (Ammon, Bickel \& Lenz, 2016), which documents lexical variation in German standard languages across countries and regions on the basis of a corpus comprising newspapers from the according areas. Furthermore, the Variantenwörterbuch des Deutschen lists geben 'give' as a PUT verb, in fact as a standard (!) variant, which-based on extensive evidence from the corpusmay be assigned to Eastern Austria and Southern Germany. An example from the corpus is this comment taken from the Austrian newspaper Die Presse from the year 2005:

geben: [ ... ] A D-süd 'etw. igendwohin stellen, legen, setzen': Am Samstag dürfen die Besucher in der Innenstadt die Kurzparkzone gratis benützen, müssen aber eine Parkscheibe hinter die Windschutzscheibe geben (Presse 8. 8. 2005, 9; A). (Ammon, Bickel \& Lenz 2016: s.v. geben)

geben: [...] A [Austria], D-South [South-Germany] 'cause to stand, lay, sit [stellen, legen, setzen] something somewhere': On Saturday, the visitors are allowed to use the short-term parking zone in the inner city for free; however, they have to put (lit.: give) a parking disc behind the windscreen (Presse, 8 August 2005, 9; A[ustria]). (own translation)

Based on the aforementioned German dictionaries, the verbs geben 'give' and tun 'do' can be identified as potential candidates for basic PUT verbs in German, which however from a normoriented perspective still carry connotations of colloquialisms and restrictions to certain areas. Nevertheless, in Eastern Austria and Southern Germany geben 'give' as a PUT verb gained acceptance as an unmarked variant in newspaper articles and therefore in standard model texts. Thus, the dictionaries allocate geben 'put' to the (East) Upper German area and therefore to an area thatconsidering its history-makes a German-Czech language contact explanation plausible.

\subsection{Geben 'put' as a "Czechism"? Language contact research}

A review of literature on language contact shows that theses concerning the impact of Slavic languages on the spread of geben 'give' as a PUT verb have been suggested as early as during the 19th century. The first mention is found in August Schleicher's paper about the mutual influence of Czech and German (Über die wechselseitige Einwirkung von Böhmisch und Deutsch; 1851), in which he lists geben 'give' for "setzen ['cause to sit'], legen ['cause to lie'], stellen ['cause to stand'], stecken ['push/stuff]" and others as an expression of "Slavic kind" and as typical for Viennese German. According to Schleicher, geben 'give' in this sense also occurs in "printed books" and therefore occasionally in standard language contexts:

Noch entschiedener tragen folgende Ausdrucksweisen den slawischen Typus an sich, die ebenfalls meistentheils auch im Wiener Deutschen, ja auch in gedruckten Büchern hier und da zu finden sind. [...] „Geben“ für setzen, legen, stellen, stecken u. s. w., z. B. „gieb es auf den Tisch, in die Tasche" = dej na stul, do kapsy. (Schleicher, 1851:40-41)

Even more obviously of the Slavic type are the following expressions, which are also frequently used in Viennese German and which now and then can even be found in printed books. [... ] "Geben" ['give'] for setzen ['cause to sit'], legen ['cause to lie'], stellen ['cause to stand'] and stecken ['stuff], etc., 
for example "gieb [sic!] es auf den Tisch, in die Tasche" $=$ [Cz.] dej na stul [sic!], do kapsy ['put it onto the table, into the pocket']. (own translation)

In his monograph Slawo-deutsches und Slawo-italienisches (Slavo-German and Slavo-Italian; 1884), Hugo Schuchardt explicitly refers to Schleicher's thesis and strengthens the Czech-German language contact hypothesis. For Schuchardt (1884), geben 'give' as a PUT verb is even a "common Austrian" phenomenon:

Geben für stellen, setzen, legen, thun (dáti), z. B. gib's auf den Tisch - in die Tasche war als Tschechismus schon Schleicher aufgefallen; es ist allgemein österreichisch; In der »Neuen Freien Presse« habe ich als Recept für Kanonverfertigung gelesen: man nimmt ein Loch und gibt Kupfer darum. (Schuchardt 1884:96).

Geben ['give'] for stellen ['cause to stand'], setzen ['cause to sit'], liegen ['cause to lie'], thun ['do'/'put'] (č. dáti ['geben']), for example, gib's auf den Tisch - in die Tasche ['put (lit.: give) it onto the table, into the pocket] had been already noticed as a Czechism by Schleicher; it is common in Austria; In the newspaper 'Neue Freie Presse', I read an instruction for cannon production, man nimmt ein Loch und gibt Kupfer darum ['one takes a hole and gives (lit.: puts) copper around it']. (own translation)

The third and most extensive evidence from the literature comes from Heinrich Teweles, a Prague born Czech-Austrian author and theatre critic who in his culture section of Der Kampf um die Sprache - Linguistische Plaudereien; Teweles 'Battle Over Language - Linguistic Chit-chat' (1884) writes:

Wo der Deutsche „setzen“, „legen“ oder „stellen“ gebraucht, da sagt der Deutsche in Oesterreich "geben“, indem er das čechische dáti übersetzt, z. B. statt: Stelle das auf den Tisch - gib das u. s. w.: dej to na stůl. Auf dem Gymnasium hatte der Professor des Lateinischen große Mühe uns auseinanderzusetzen, daß man ein so falsch gebrauchtes "geben“ nicht mit dare, sondern mit ponere übersetzen müsse, welches Wort ja viel anschaulicher und genauer ist. (Teweles 1884:104)

Where Germans use "setzen" ['cause to sit'], "legen" ['cause to lie'] or "stellen" ['cause to stand'], Germans in Austria say "geben" ['give'] by translating the Czech dáti ['give'], e. g., instead of Stelle das auf den Tisch - gib das and so on: dej to na stül. In high school our professor of Latin had great difficulty explaining to us that such a wrongly used geben cannot be translated by dare ['give'], but has to be translated by ponere ['put'], which supposedly is much more illustrative and precise. (own translation)

In the context of the earlier mentioned corpus-based evidence from the dictionary of varieties in German, this review of historical literature on German-Slavic language contact provides a clear and consistent picture that will be further examined in the following empirical analyses. As a prerequisite, the sociolinguistic perspective must be taken into account (for methodological considerations cf. Kim \& Prochazka, 2019:6-7): In Muysken's (2013:723) framework, the correspondence of the PUT meaning of the GIVE verb in Czech and neighboring German varieties can be described as a "convergent change due to partial overlap in meaning or form between elements in the two languages." Such a linguistic outcome requires a specific contact scenario, namely prolonged stable bilingualism (cf. Muysken, 2010:272). As several studies have shown, this was the case not only in Bohemia, Moravia, and Austrian Silesia (cf. Berger, 2009, 2014; Newerkla, 2002, 2011, 2017; Skála, 1964), but also in parts of Lower Austria (cf. Kim, 2019). From a sociolinguistic perspective, the language contact explanation thus seems plausible.

It is important to point out that the scenario approach does not neglect or ignore the role of the multilingual individuum as the "locus of language contact" (Weinreich, 1979 [1953]:1).
Comparatively, it describes the societal conditions that may affect the individuum's language use. For multilingual speakers in a different, contemporary scenario of prolonged stable bilingualism, primarily for speakers of Sursilvan Romansh and German in Switzerland, Berthele $(2012,2014)$ has investigated usage patterns of PUT verbs. In contrast to German, which in its standard varieties uses a wide range of specifying verbs for the expression of PUTTING events, Sursilvan Romansh prefers the basic verb metter 'put'. Berthele $(2012,2014)$ identified bilingual speakers who transferred the Romansh pattern to German and thus tend to use either tun 'do' or even legen 'cause to lie' generalized in almost all PUT contexts. These results provide evidence that the transfer of such usage patterns is possible. The existence of a basic PUT verb in the source language is the necessary condition.

\subsection{GIVE as a PUT verb in Czech}

Considering the high degree of polysemy of Czech dáti $(=\mathrm{pf}$. dát [se]/ipf. dávat [se]/iterat. dávávat [se] $)^{14}$ 'give', it is hardly surprising that in Czech, it ranks amongst the most frequent verbs (9th place) and words in general (81st place, cf. Blatná et al., 2004:375). The main academic Standard Czech dictionaries of the 20th century (Hujer et al., 1935-1957 [PSJČ]; Havránek et al., 1960-1971 [SSJČ]; Filipec et al., 1994 [SSČ]) and the Treebank-based Valency dictionary of Czech VALLEX (Lopatková et al., 2016) record up to 14 (non-idiomatic) meanings for the respective verb. Amongst these, the use of dáti 'give' as a PUT verb is prominent. It can be used as a basic PUT verb for both fluid and solid objects and for every possible object's final orientation (cf. [14-19]). In all cases, however, it alternates with respective specifying verbs.

\begin{tabular}{|c|c|c|c|c|c|c|}
\hline \multirow{4}{*}{ (14) } & \multirow[t]{2}{*}{ a. } & \multicolumn{2}{|l|}{ dát } & \multirow{2}{*}{$\begin{array}{l}\text { vázu } \\
\text { vase.Acc }\end{array}$} & \multirow{2}{*}{$\begin{array}{l}n a \\
\text { on }\end{array}$} & \multirow{2}{*}{$\begin{array}{l}\text { stůl } \\
\text { table.Acc }\end{array}$} \\
\hline & & give.INF & & & & \\
\hline & b. & postavit & & vázu & $n a$ & \\
\hline & & cause to stand.INF & & vase.Acc & on & table.Acc \\
\hline \multirow[t]{4}{*}{ (15) } & a. & dát & & knihu & do & kufru \\
\hline & & give.INF & & book.ACc & into & suitcase.GEN \\
\hline & b. & vložit & & knihu & do & kufru \\
\hline & & cause to lie.INF & & book.Acc & into & suitcase.GEN \\
\hline \multirow[t]{4}{*}{ (16) } & a. & dát & si & klobouk & $n a$ & hlavu \\
\hline & & give.INF & REFL.DAT & hat.Acc & on & head.Acc \\
\hline & b. & nasadit & si & klobouk & $n a$ & hlavu \\
\hline & & cause to sit.INF & REFL.DAT & hat.Acc & on & head.Acc \\
\hline \multirow[t]{4}{*}{ (17) } & a. & dát & & hadr & do & diry \\
\hline & & give.INF & & cloth.ACC & into & hole.GEN \\
\hline & b. & nacpat & & hadr & do & diry \\
\hline & & stuff.INF & & cloth.ACC & into & hole.GEN \\
\hline \multirow[t]{4}{*}{ (18) } & a. & dát & & hůlku & do & hlíny \\
\hline & & give.INF & & stick.ACC & into & soil.geN \\
\hline & b. & strčit & & hůlku & do & hlíny \\
\hline & & push.INF & & stick.ACC & into & soil.gen \\
\hline \multirow[t]{4}{*}{ (19) } & a. & dát & & vodu & do & vany \\
\hline & & give.INF & & water.ACC & into & tub.GeN \\
\hline & b. & nalít & & vodu & do & vany \\
\hline & & pour.INF & & water.ACC & into & tub.gen \\
\hline
\end{tabular}

The emergence of the PUT semantics appears to have captured little attention in research so far. The only study to take account of it does so from a Czech-Russian contrastive perspective: Žaža 
(2001:231; 2006:130) observes that the Russian equivalent (and cognate) damb $\mid$ dat' 'give' does not have a PUT meaning and points out that the according Czech construction resembles the use of German geben 'give'.

In order to establish contact explanations, synchronic-contrastive analyses are not sufficient and a diachronic perspective is required. The Elektronický slovník staré češtiny 'Electronic Dictionary of Old Czech' (ESSČ, Fuková et al., 2006-: s.v. dáti) lists several of the aforementioned meanings of the verb dát i 'give'. In its literary meaning as a GIVE verb it is described as a "verb of transfer" and in its PUT verb semantics as a "verb of placing an object." The PUT verb function of dáti 'give' seems to have been well established at latest towards the end of the Old Czech period (approximately $1150-1500)$, as the following examples (20-22) from the OldCzech Text Bank (Staročeská textová banka, STB v. 1.1.8.) imply.

(20) Obrátím púšč v jezera vodná a zemi bezcěstnú v potoky vodné. Dám na púšči cedrové dřěvo a trn a myrtus, dřěvo vonné a dřěvo olivové. Postavím na púšči jedlu a pušpan spolu, [ . . . ]

'I will turn the desert into lakes of water and the pathless land into water brooks. I put (lit.: give) cedar wood and briar and myrtle in the desert, fragrant wood and olive wood. I will put a fir tree and a box tree together in the desert [...]'

(Proroci rožmberští [Prophets of Rožmberk]; turn of the $14^{\text {th }} / 15^{\text {th }}$ century)

(21) [...] a také rád [...], kterým zasliboval Pán Buoh Davidovi, že vždy dá na stolici jeho potomek etc.

'[...] and also the covenant [...], by which God the Lord promised David that he will always put (lit.: give) his descendants on the throne, etc.'

(Žídek, Pavel: Spravovna [an advice manual entitled Spravovna for George of Poděbrady, this Speculum Principis (Mirror for a Prince) was a guide to proper princely behaviour]; last third of the $15^{\text {th }}$ century)

(22) Šla vesele do žaláře, jako by byla na hody zvána, a nestrachovala sě pro milého hlavy dáti pod meč břidký.

'She merrily went to jail, as if she had been invited to a feast, and for her dear one she was not afraid of putting (lit.: giving) her head under the sharp sword.'

(Štítný ze Štítného, Tomáš: Řeči nedělní a sváteční, rukopis $B$ [Sunday and holiday orations, manuscript B]; around 1500)

The examples provided illustrate that dáti 'give' was already used in various PUT contexts in Old Czech, namely: 'cause to stand' (20), 'cause to sit' (21) and 'cause to lie' (22). Example (20) is particularly instructive since its sequence of parallel-structured sentences contains the synonymous verbs dáti 'give' (here: 'put') and postavit 'cause to stand'.

However, such constructions cannot be found in Church Slavonic. Depending on regional uniqueness, various Church Slavonic redactions (or recensions) were used as a liturgical and literary language in all Orthodox countries north of the Mediterranean region during the Middle Ages, even in places where the local population was not Slavic, e.g., in Romania. Old Church Slavonic dictionaries, both with a focus on the Southern redactions (Ivanova-Mirčeva, Davidov \& Ikonomova, 1999: s.v. dati [Bulgarian]; Hauptová, Klenovar \& Mulc, 2008: s.v. dati [Croatian]) and Western redactions (Kurz et al., 1958: s.v. dati) do not include the PUT construction. However, in the other sacred and prestigious language in Bohemia and Moravia, Latin, the equivalent of Cz. dáti 'give', Lat. dare 'give', seems to have had PUT semantics, too (cf. Georges, 1913: s.v. do [2]; Ryba \& Martínek, 1992: s.v. do). A diachronic analysis of the development of different semantics and functions of equivalents of 'give' in Central European languages and their varieties would therefore also have to consider a possible influence of (Medieval) Latin.

\subsection{PUT verbs in other contemporary Slavic languages}

The following section aims to identify whether other Slavic languages than Czech have also grammaticalized a basic verb for PUT constructions and if so which one. The data stems from the parallel translational corpora within the InterCorp of the Czech National Corpus (cf. Čermák \& Rosen, 2012; Rosen, 2012; Rosen \& Vavř́n, 2012; and for a usage-oriented review Kim, 2018a; https://www.korpus.cz/), namely from v.9 (Rosen \& Vavř́n, 2016), which can be searched via the Translation equivalents database (Treq; cf. Škrabal \& Vavř́n, 2017; https://treq. korpus.cz/).

While obtaining our data, we departed from English, i.e., a language with a prototypical basic verb as a PUT verb. The EnglishSlavic subcorpora were explored separately for the translation equivalents of English 'put' via Treq, an application which allows to search either Czech-foreign or English-foreign dictionaries built automatically from the InterCorp v9 for translation equivalents of words or phrases. Depending on the availability of lemmatized subcorpora, these dictionaries can also be examined for translation equivalents of lemmata. In this study, only Slavic languages with lemmatized subcorpora in v9 were included, i.e., the Belorussian, Ukrainian, Bulgarian, and Macedonian parts of the InterCorp had to be excluded. Additionally, we focus on possible genre-specific variation of basic and specifying verbs in these languages in the same step. Therefore, the two parts of the InterCorp that are available for all English-Slavic language pairs were examined separately. They represent the possibly most divergent genres in the InterCorp, namely the automatically aligned subtitles, which resemble colloquial spoken language in many ways, and the manually aligned core, which comprises contemporary fiction and poetry exclusively.

Figure 2 illustrates the results of this rather quantitative contrastive analysis. It allows for the following conclusions:

Generally, the use of cognates of Cz. dáti 'give' as a translation equivalent for English 'put' is only common in four out of the seven languages. All of the languages (Czech, Slovak, Slovenian and Croatian) are spoken in areas of Central Europe that belonged to the Habsburg state from the Middle Ages onwards. The only Central European language that does not (or: not frequently) use its equivalent of 'give' as a PUT verb, is Polish, which is well known for its semantic granularity of placement expressions (cf. Kopecka, 2012). This analysis does not, however, consider diatopic, diachronic, and diastratic variation in Polish. As section 4.1.3 (and especially Map 2) in this study indicates, dać was definitely used as a PUT verb in Silesian dialects in the 19th century and is possibly still in use today.

Three languages (Czech, Slovak and Slovenian) show especially high relative frequencies of the respective verbs Cz. dáti (35.1\%), Slovak dat' (34.8\%) and Slovenian dati (28.5\%). In all these languages, the frequency is higher in the subtitles subcorpus, i.e., in the subcorpus of the more informal/colloquial text type.

Similarly, Croatian dati (2.4\%) only appears in the subtitles subcorpus. Although it is not a frequent translation equivalent of English 'put', it is the most obviously different when compared to the Serbian ranking. Considering that Serbian and Croatian are linguistically very close, the fact that the area where Croatian is spoken nowadays was part of the Habsburg state 


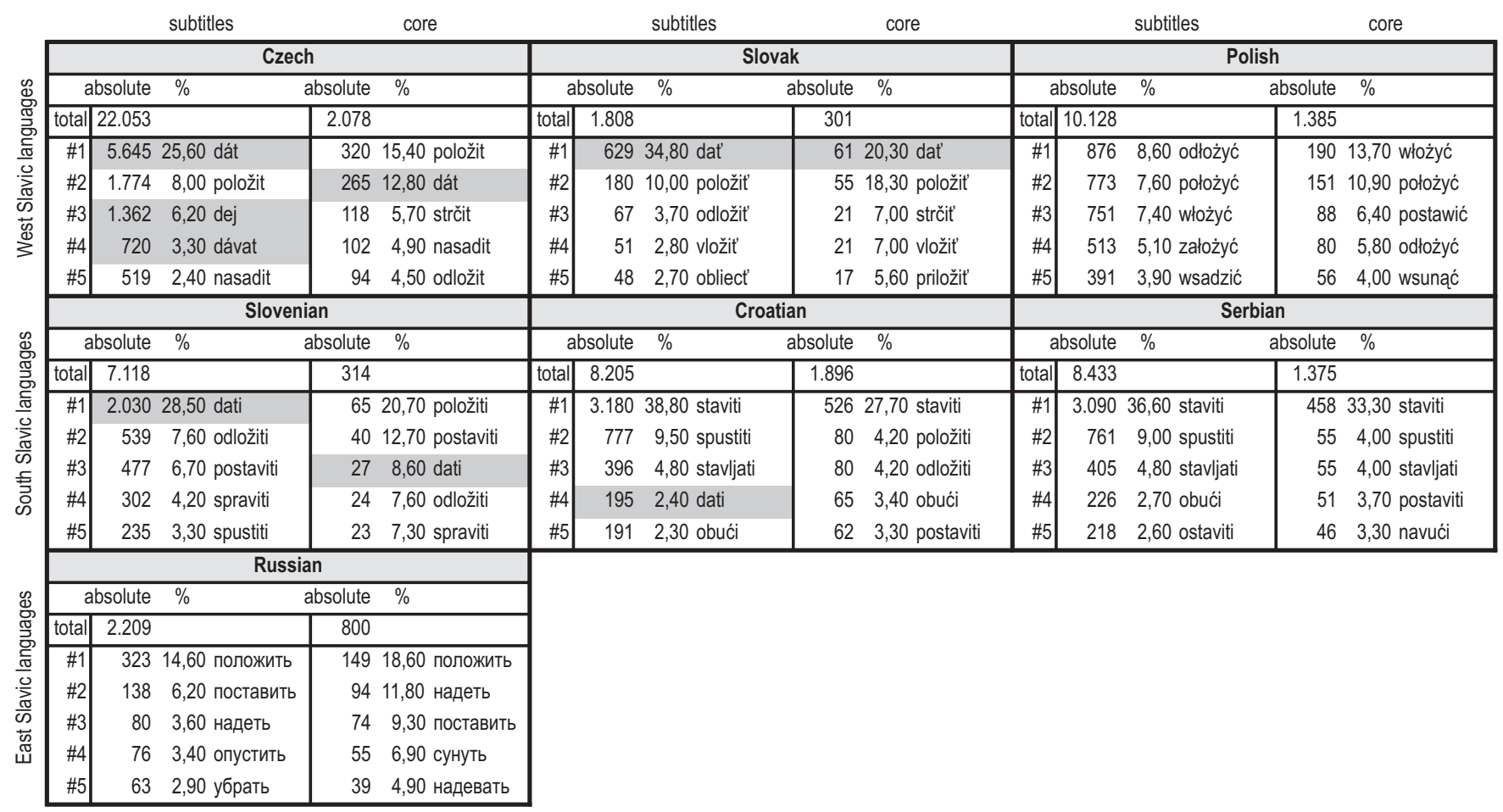

Figure 2. Most frequent translation equivalents of the English lemma put in a selection of Slavic languages, extracted via the application Treq from the subtitles and core subcorpora of the InterCorp v.9. Cognates of Cz. dáti 'give' are highlighted in grey. (The results were not checked manually.)

becomes even more striking. However, a closer qualitative examination is required. Such an analysis should also consider areal variation in Serbian, e.g., by considering the varieties used in the Autonomous Province of Vojvodina, the northern part of Serbia, which also belonged to the Austro-Hungarian monarchy.

Croatian and Serbian both have established another basic PUT verb, namely staviti 'put'. In Russian, položit' 'put into a lying position' is considerably more frequently used as a translation equivalent of 'put' than other lexemes. Polish is the only language where no dominant PUT verb seems to have emerged and various derivations of the verb *łożyć 'cause to lie, put' appear in the corpus.

The results indicate that the use of GIVE verbs as basic PUT verbs is essentially a Central European phenomenon and possibly restricted to languages and varieties used in the area of the former Habsburg Empire. Contemporarily, this specific function of GIVE verbs appears more frequently in informal/colloquial varieties. In Czech, however, it has been part of the literary language since-at latest - the 15th century. Considering that it is not registered for Old Church Slavonic, a Slavic origin of the lexicalization pathway is less likely than the replication of Medieval Latin constructions. Both the areal distribution of the phenomenon and its emergence and spread, however, require further in-depth investigations, which consider all the aforementioned aspects of variation. This paper cannot account for all of them, but provides thorough insight into the distribution in the German-Czech contact area and the development throughout the 20th century.

\section{Analyses into PUT verbs in German}

\subsection{Wenker survey at the beginning of the 20th century}

In the late 19th century, the Marburg-based dialectologist Georg Wenker started his unique survey on dialects of German in order to create the Linguistic Atlas of the German Empire (Sprachatlas

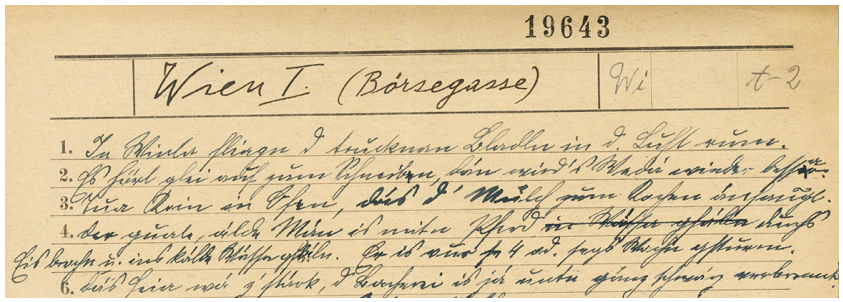

Figure 3. Part of a Wenker questionnaire (front page) filled in in Vienna (1. district, Börsegasse)

des Deutschen Reichs). The main data collection took place between 1876 and 1887 (cf. Schmidt \& Herrgen 2011:97-107). In 1888, and between 1926 and 1933, additional data collections were conducted, investigating other German-speaking countries and regions (including Austria, Switzerland, Luxemburg, and the German-speaking parts of former Czechoslovakia). Wenker's method was simple yet effective: he sent a two-page questionnaire to every school and asked the local teachers to translate approximately 40 given sentences into the local dialect. If the teachers were not originally from the town they were teaching in, they were asked to translate the sentences with the help of their students. Figure 3 shows the front page of one Wenker questionnaire completed in Vienna (1. district, Börsegasse) by the teacher Maria May, a Vienna local (personal data concerning the teachers was asked on the second page of the questionnaire).

The data of the main data collection (1876-1887) were included in the atlas using large and colorful language maps. However, the questionnaires of the later, additional surveys (such as those from Austria and former Czechoslovakia) did not find entrance into Wenker's Linguistic Atlas of the German Empire. Because Wenker's main interest was the phonologic diversity of the various 


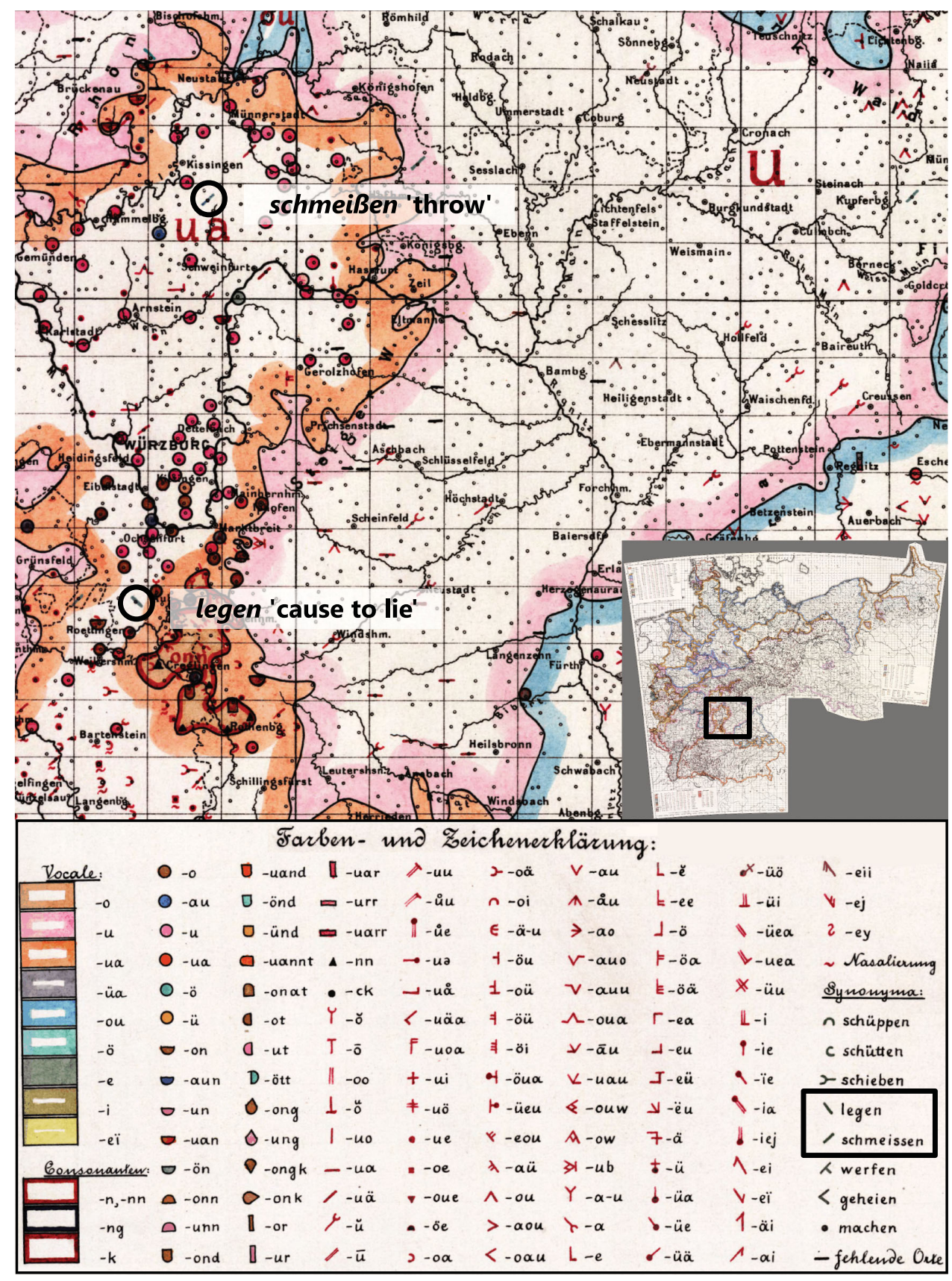

Map 1. Part of the Wenker map (Eastern Upper German) for sentence \#3 $t(h) u$ 'do' (region Würzburg in Southern Germany, Bavaria) with a focus on the initial vowel (and where applicable on the consonant in the final position), including a part of the legend. Created with $<$ regionalsprache.de>. dialects, the mapping of the dialects also primarily aimed to portray differences in phonetics and phonology. Concerning the verb $t(h) u$ 'put' in Wenker sentence \#3 Thu Kohlen in den Ofen 'Put coal into the stove', this means that the maps should portray variations in consonants and vowels in the best possible way. It is only by looking closely at the legend of this phonetic map, that one can find also lexical variations (cf. Map 1).

\subsubsection{Analysis of Wenker sentence \#3: Method}

Wenker sentence \#3 is of particular interest, as it is (apart from one sentence with a BRING act) ${ }^{15}$ the only sentence with a verbalized PUT act. As we demonstrate, Wenker's data can be used to illustrate lexical variation, even if this was not Wenker's original intention. However, as it is not possible to get a comprehensive picture concerning lexical diversity through Wenker's maps and as there are no maps available for our areas of interest, namely contemporary Austria and Czechia, we decided to analyze sentence \#3 again. When it comes to generating overview maps, the immense size of the corpus makes it particularly important to work with balanced samples. Our study is based on a broader sample ("sample I") and a second sample used for an in-depth investigation ("sample II"):

Sample I: The first data sample used in this study was kindly provided by Jürg Fleischer from the University of Marburg, who created it to illustrate morphological and syntactical variation of pronominal constructions (cf. Fleischer, 2015:194). Following Glaser (2008:101), Fleischer assumed that syntactical phenomena are distributed in larger areal patterns than phonological ones; hence, a significant reduction of his potential dataset was justified. Fleischer's (2015) results not only confirm this assumption, but 
Map 2. Lexical variation for the verb tun 'do' (here: 'put') in Wenker sentence \#3: Thu Kohlen in den Ofen [...] 'Put coal into the stove'. Based on 2,316 Wenker questionnaires ("sample I"), available via $<$ regionalsprache.de $>$.

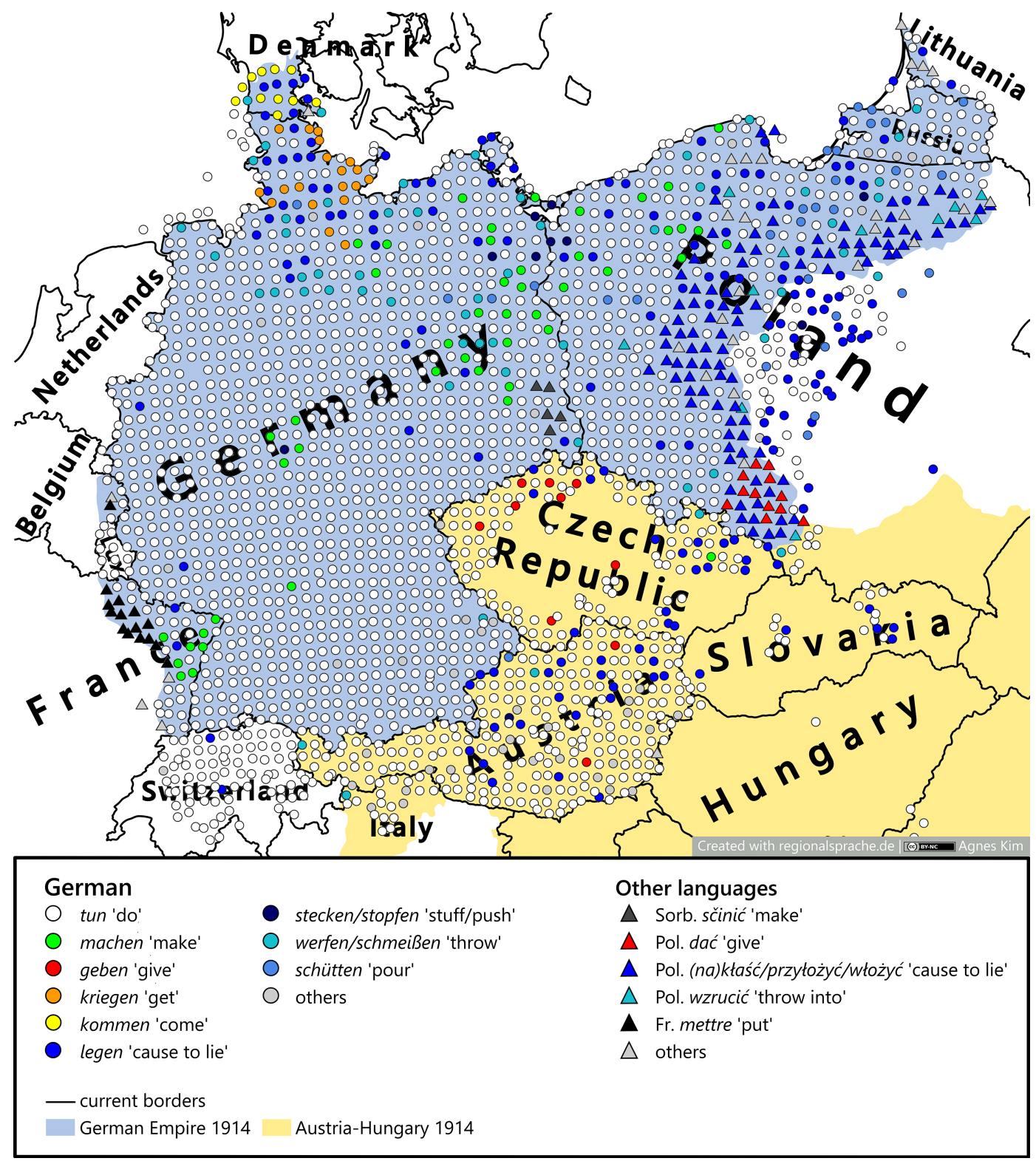

also refute the preconception that Wenker's data was too limited in syntactical variants. Fleischer's survey has shown that clear areal patterns of syntactic variation can be easily mapped based on a sample size of approx. 2,000 questionnaires.

The current study extends the method to lexical variation. With regard to sample composition, a numerical method was rejected in favor of a geographical approach. ${ }^{16}$ That means that the questionnaires were not selected randomly. Instead, a balanced distribution across the entire (partly historical) German-speaking area was ensured. As an additional benefit, this type of selection facilitates the direct depiction of areal patterns; however, other factors are neglected, such as varying population densities.

For this purpose, a geogrid with a regular shaped pattern of squares with sides of $18 \mathrm{~km}$ in lateral length was placed over the relevant geographical area. For each quadrant, a questionnaire was taken from the point nearest to the geometric center, provided some conditions - such as a high degree of completeness-were fulfilled. Eventually, the resulting sample consisted of 2,316, evenly distributed questionnaires, and more than $90 \%$ were filled out in
German. Nine other languages account for the remaining 200 questionnaires, of which Polish is the most common (cf. Map 2).

Sample II: To cover the Central European contact area at the former German-Czech language border in more detail, all questionnaires within the territory of the current Czech Republic build the second data sample of in-depth investigation. It is crucial to keep in mind that the data collections for the German Linguistic atlas in the early 20th century did not primarily focus on geographical and political entities anymore, but rather on (German) linguistic communities outside the original area of investigations, i.e., the former German Empire, many of which were distributed over different nation states which emerged from the fallen multiethnic Habsburg state. Consequently, the 3,372 questionnaires from Bohemia, Moravia, and Austrian Silesia do not capture the existing linguistic diversity, as all were filled out in German (for the survey history in Czechoslovakia cf. Fleischer, 2017:94; Kim, 2018b:282-284 and 289-294).

Even though the current political border between Austria and the so-called lands of the Bohemian crown has been relatively 
stable since medieval times, it was not until the interwar-period that it became a national border, dividing German-speaking communities in Northeastern Austria and Southern Bohemia and Moravia. It can be assumed that the state boundary of the Habsburg Empire-in contrast to the language border-did not concern the vast majority of German speakers during the time preceding World War I (cf. Cornwall, 1994:914). In order to expand the investigated area further south, data from Northeastern Austria was added to the sample. For practical reasons, we defined an extended contact zone between the Austrian-Czech border and the Danube. To a large extent, it is identical with the linguistic micro-area in Eastern Austria and Vienna described by Newerkla (2007a, 2007b). Due to long-term intense contact of varieties of German and Czech in this region, these varieties are shaped by a number of convergent features. Hence, another 850 questionnaires found entrance into Sample 2, completely covering the relevant area.

\subsubsection{Results}

Map 2 visualizes the results from sample I. The map comprises the whole area investigated in Wenker's survey, from the Danish border in the North down to South Tyrol, and from the East to the West from Lithuania to Alsace, respectively. German Wenker's questionnaires are illustrated as points; those in other languages as triangles. As indicated by the legend (cf. Map 2), next to German questionnaires there are also Polish, Sorbian and French questionnaires represented in the sample under analysis. The category "other (foreign languages)" comprises verbs of other foreign languages for which the minimal number of five recorded sentences was not reached.

Various categories of verbs are differentiated through colorcodes (cf. legend in Map 2). Considering that the vast majority of points in the graph are white, it can be said with certainty that tun 'do', as it was suggested by the Standard German stimulus sentence \#3, is the most widely distributed positioning verb in our sample. For our analyses, however, the points with a color other than white are particularly interesting, namely those places where the teachers did not use the verb tun 'do' in their translations. These deviations do not provide negative evidence, i.e., the (relatively unlikely) possibility of a local non-existence of tun 'do' as a PUT verb. The lexical variants only prove that the teacher did not think of tun 'do' as suggested by the Standard German stimulus as the best verb for the translation into the local dialect, which made them consequently (deliberately or subconsciously) choose another lexical variant.

Among these deviations are a few other basic verbs, but also specifying verbs. Two of the frequently used basic verbs that occur next to tun 'do' are German machen 'make' (green dots) and French mettre 'put' (black triangles). Specifying verbs that were found in the records are: legen 'cause to lie', stecken/stopfen 'push/stuff, schütten 'pour' or werfen/schmeißen 'throw' that give evidence for different traditions in lightening the stove or that occur for different fuels (in the accusative object; e.g., wood instead of coal).

The frequently occurring dark-blue triangles in the East (cf. Map 2) show that, in the Polish questionnaires, verbs that mainly denote a placement act which results in the object lying somewhere were used: kłaść (ipf.)/nakłaść (pf.) 'cause to lie', przyłożyć (pf.) 'cause to lie close to something' and włożyć (ipf.) 'cause to lie in something'. Alongside these verbs, there is only Polish dać 'give' (red triangles), which spreads over the Opole Voivodeship (historic
Upper Silesia), and Sorbian sčinić 'do/make' (dark grey triangles) in Lusatia.

All the other verbs that occur in sample I at least five times are basic movements verbs of German: one of those is the German verb kommen 'come', which can generally be categorized as a verb of subject movement in German (cf. Map 2). As shown in Map 2, kommen 'come' carries PUT semantic in parts of northern North Lower German, just as this is the case in neighboring Danish, which has also developed a PUT semantic for its basic COME verb.

For at least nine places, examples of geben 'give' were recorded and their regional distribution strongly supports our language contact hypothesis. The examples can only be found in the area of German-Czech bilingualism and thus language contact in North-Western Bohemia and in Austria, respectively. That those nine records do not happen to be situated along those borders incidentally is supported by sample II. As shown in Map 3, Wenker's questionnaires of the German-speaking regions of former Czechoslovakia as well as the questionnaires from north of the Danube river provide numerous examples of geben 'give' for this language contact area. These results may be considered empirical evidence for the language contact hypothesis proposed by Schleicher, Schuchardt and others in the 19th century. ${ }^{17}$ In the following, this first evidence will be supported by a second more recent data source.

\subsection{Questionnaire survey on dialects at the beginning of the 21st century}

\subsubsection{Research method}

Our second database stems from a questionnaire survey conducted in 2010, which primarily focused on syntactical phenomena (cf. Lenz, Ahlers \& Werner, 2015) and in which lexis was only of minor importance. The survey included the complete Bavarian language area in the South West of Germany, major parts of Austria as well as South Tyrol in Northern Italy. All interviewees claimed to be highly or fully competent speakers of the local dialect, which is reflected in their frequent (or very frequent) use of the dialect in everyday life. There were two groups of speakers. The interviewees of the older generation ('old') represent classic NORMs/NORFs: they are pensioners aged 65 or older, who have only received basic education and who have followed a manual occupation in their village or at least in the close surroundings. The second is a younger group (aged between 20 and 30 years), which does not only differentiate itself from the older group through its age, but also through higher education, a strongly communication-oriented profession and higher regional mobility, which is reflected in daily or weekly commutes between the place of residence and the place of work. There is a possibility that interviewees from this group are still pursuing their studies or training. Consequently, we can differentiate between two potential "extreme groups" of dialect speakers: on the one hand, the potentially most conservative type of an older, less mobile dialect speaker; on the other hand, the potentially most progressive type of a younger, highly mobile dialect speaker.

Altogether, 105 older informants in 34 villages participated in the pilot study; the average age was 67.7 years. Their places of residence and consequently the places examined in the study are scattered across 16 smaller regions distributed amongst the three subareas North, Central, and South Bavarian according to Wiesinger's map for the classification of dialect areas (Wiesinger, 1983). Places with village-like characteristics and between 500 and 2,000 inhabitants were primarily investigated. For every region (symbolized in form of little squares in Map 4), 


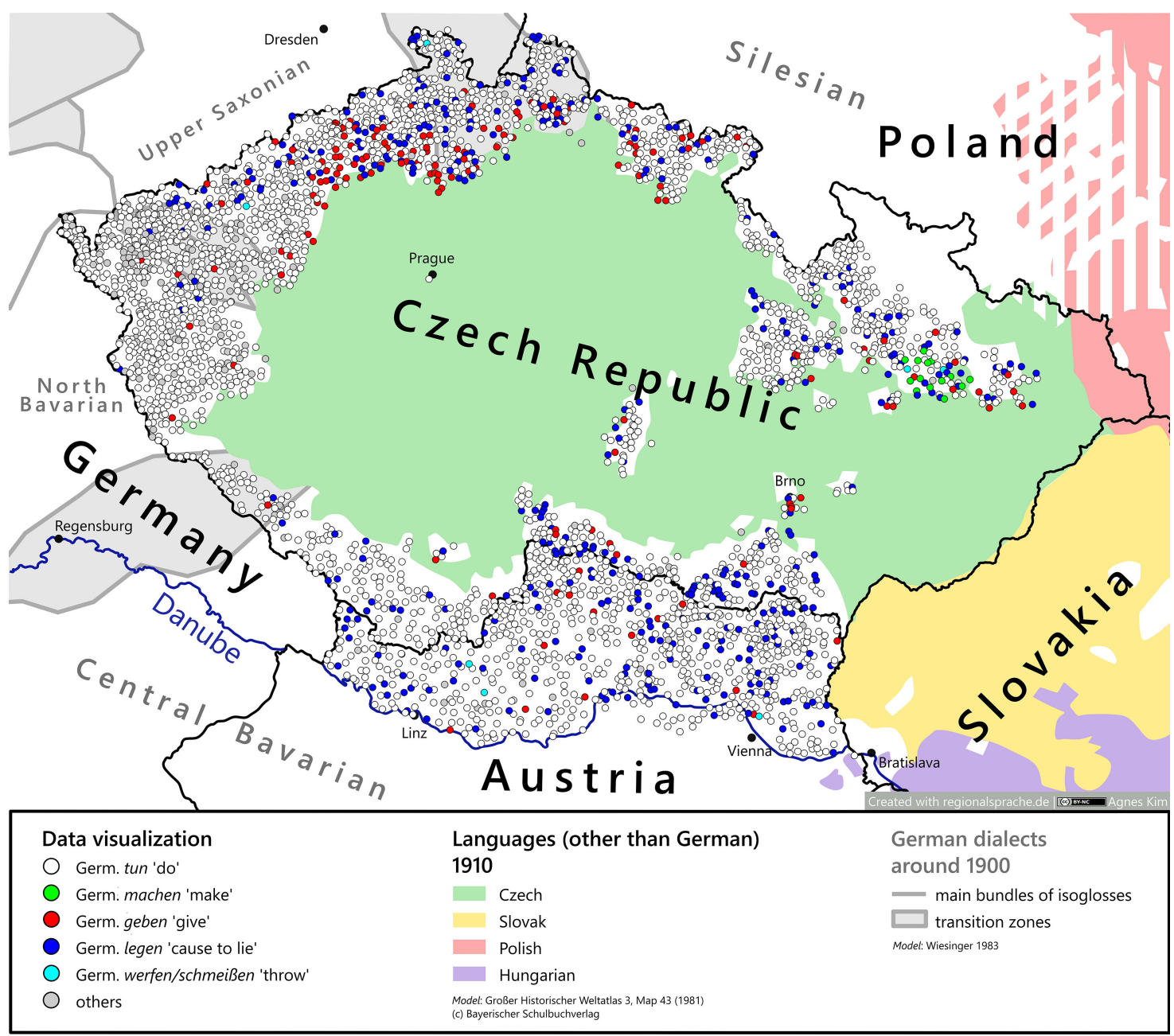

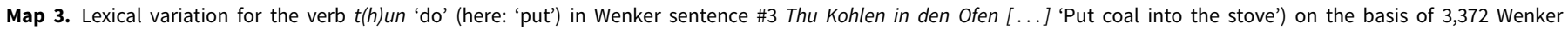
questionnaires in the German-speaking regions of former Czechoslovakia and the North of Austria ("sample II").

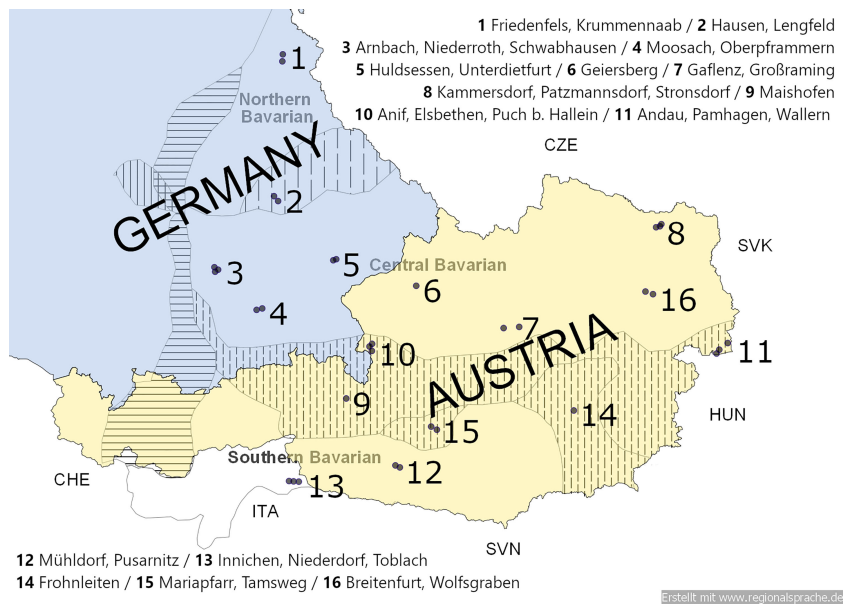

Map 4. Places of data collection $(n=34)$ and regions $(n=16)$ of data collection of the older informants ( $n=105)$; background: classification of the Bavarian language area according to Wiesinger 1983.

three to ten older speakers from (at least) three villages in the region took part in the survey. They were recruited with the help of parish council chairpersons and other mediating people and contacted by mail. In contrast, the 340 younger informants were asked to fill out the questionnaire online. The average age of the younger interviewees was 23.8 years; the regional distribution of the 242 places of data collection can be seen in Map 5. For most of the places there is only data from one single younger informant, for bigger cities (especially for Vienna) up to 22 younger interviewees took part in the pilot study.

The data examined in the following section was elicited by a so called "assessment question" that was created and established in the DFG project Syntax of Hessian dialects (www.syhd.info) (cf. Figure 4). After a short (Standard German) introduction story, stimuli (transcribed to resemble the local phonetic articulation) were presented together with the task: "Please tick the sentences, which you would use in your dialect (multiple answers possible)." Apart from the sentences that were stated explicitly, the interviewees had the option to formulate their own answers; they were asked: "Would you normally say this sentence differently, in a way that is not given here? If yes, how would you say it?" Finally, the interviewees were asked to select the most "natural" statement. In the concrete example (cf. Figure 4), the introduction story read as follows:

Franzl [typical Bavarian first name in the diminutive form] has a new girlfriend, who is coming to visit him for the first time. Nervously he is cleaning his room. Under his desk he finds old schoolbooks of his brother Karl. Franzl asks Karl: 


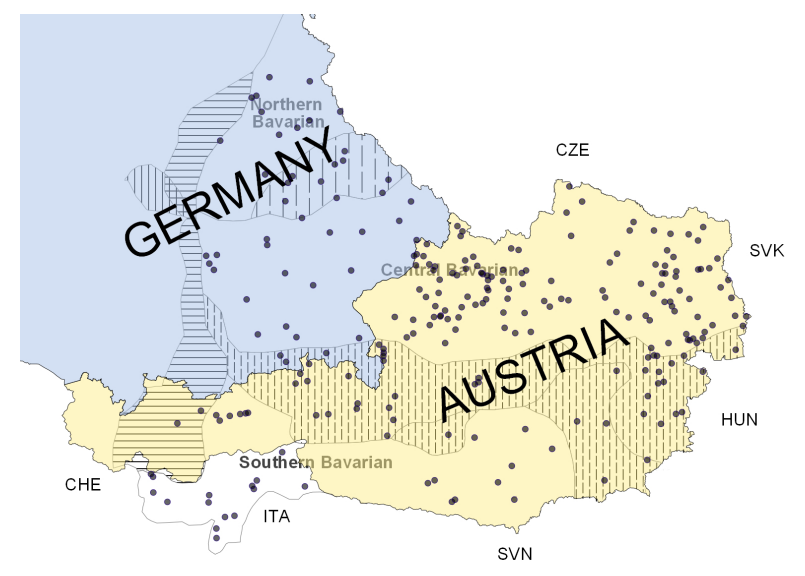

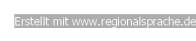

Map 5. Places of data collection ( $n=242$ ) of the younger informants $(n=340)$; background: classification of the Bavarian language area according to Wiesinger 1983.

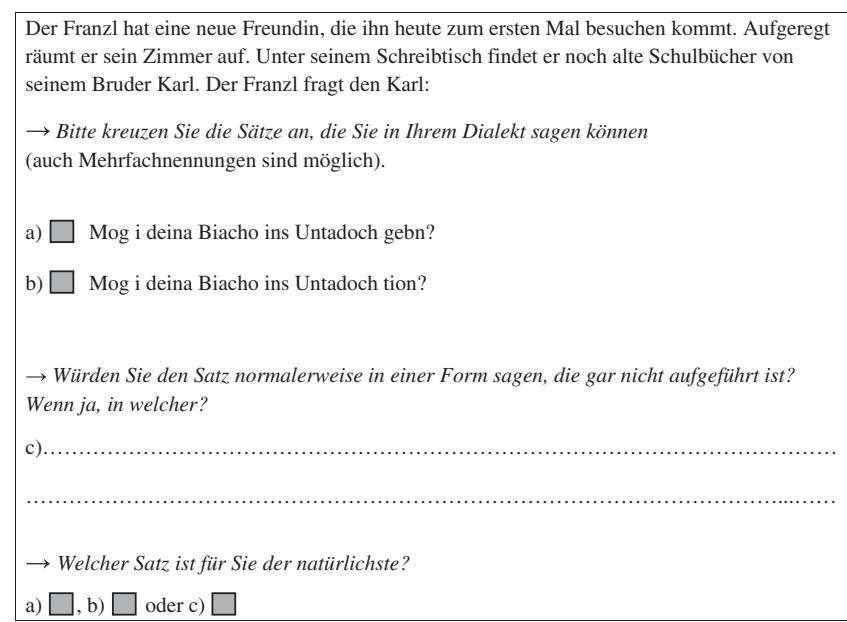

Figure 4. Task including placement verbs geben 'give' and tun 'do' in the Bavarian language area ("assessment question" according to SyHD).

Through this introductory contextualization, the simulated communicative situation was embedded into an everyday family situation, and thus into a situation where dialect is potentially used. The given stimuli referred to a PUT activity, in which the agent (ich 'I') moved books (direct object) to the attic. The stimuli differed only in the positioning verb, which in one case was the basic verb geben 'give' (answer a) and in the other case the basic verb tun 'do' (answer b). Even if there is a variety of other verbs that can be used in this context (moving something to the attic), specifying verbs were not offered on purpose to ensure that we always gained judgements concerning the basic verbs. Still, some informants made use of the possibility to formulate their own possible answers (cf. below).

\subsubsection{Results}

Maps 6 and 7 first show the results for the older generation, for which the data has been subsumed under the regions under research. One circle therefore represents the answers of three to ten informants from up to three places (for the place distribution cf. above Map 4). The red circle segments indicate the percentage of people, who named geben 'give' as a possible or even the preferred

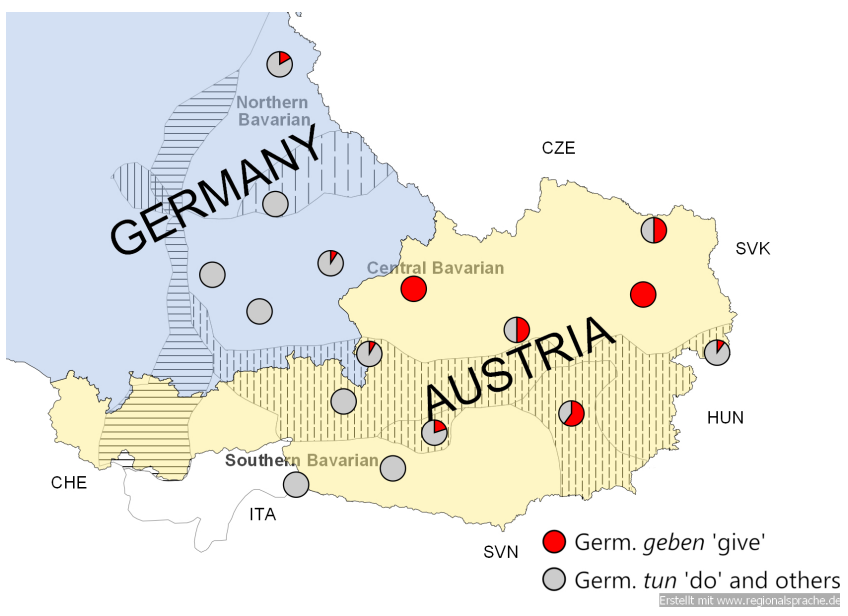

Map 6. Relative frequencies of older informants who named geben 'give' (as a placement verb in the given context) as "a possible variant" (red circle segments), $\mathrm{n}=18$.

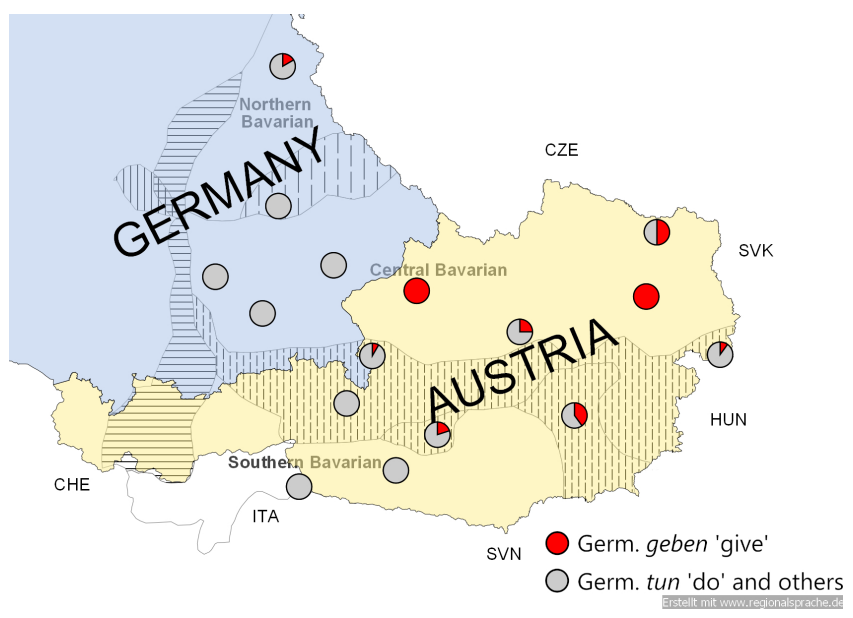

Map 7. Relative frequencies of older informants who named geben 'give' (as a placement verb in the given context) as "the most natural variant" (red circle segments), n=15.

variant in the above-mentioned context. As can be seen, both maps clearly show that geben 'give' is more accepted and is used more often in the East of the Bavarian area under analysis.

Grey circle segments represent "other" verbs. However, apart from three answers, all verbs in the "other" category refer to the verb tun 'do', which was given as the second stimulus. With the exception of two regions of data collection, the data show that tun 'do' can be used as a basic verb in the given context across the whole Bavarian language area. Only once the verb tragen 'carry' and twice the verb bringen 'bring' are named as further "possible" alternatives. ${ }^{18}$ The parts of the red circle segments for geben 'give' as "the most natural" variant (Map 7) represent a real subset of the regions with a possible use of geben 'give'. The overlap in the areal structures again confirms the validity of the data.

Maps 8 and 9 represent the answers of the younger informants, which show a surprisingly similar areal structure to those from the older generation and furthermore indicate a tendency for further distribution of the geben 'give' variant. Particularly in the Eastern parts of South Bavarian, interviewees chose the geben 'give' stimulus as a possible or the preferred variant. More often than with the older generation, "other" variants—next to the still predominantly 


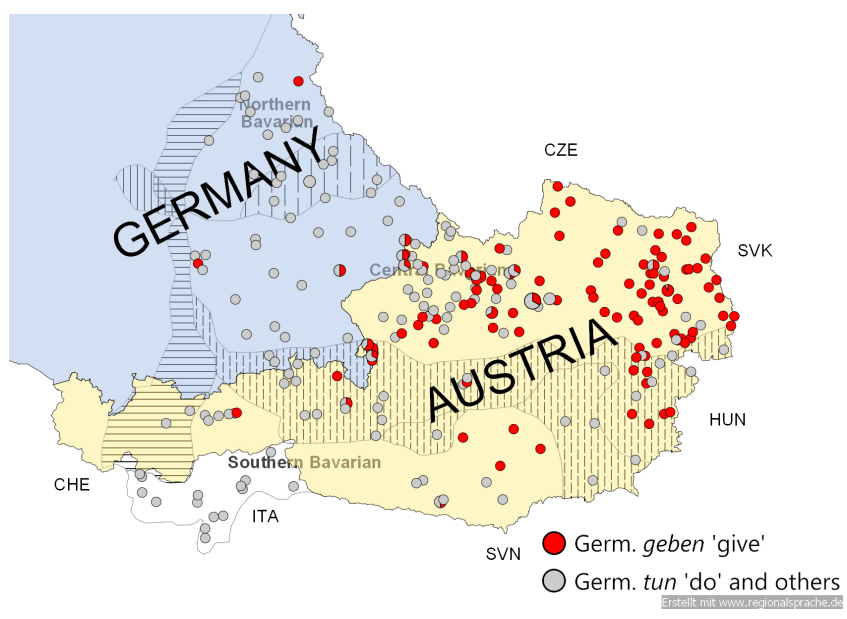

Map 8. Relative frequencies of younger informants who named geben 'give' as a placement verb (in the given context) as "a possible variant" (red circle segments), $\mathrm{n}=151$.

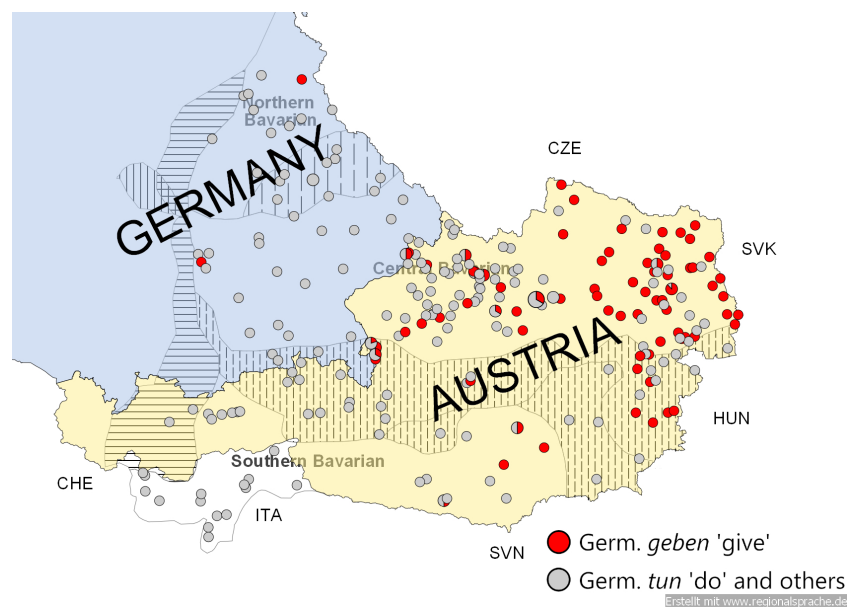

Map 9. Relative frequencies of younger informants who named geben 'give' as a placement verb (in the given context) as "the most natural variant" (red circle segments), $n=110$

used tun 'do'-are additionally provided by the younger speakers: 14 times räumen 'put away', five times bringen 'bring', four times tragen 'carry', and one answer for each stellen 'cause to stand' and legen 'cause to lie'. However, these alternatives are only named as further possibilities next to geben 'give' and tun 'do', which are considered "possible" or "most natural" throughout the area of investigation.

Altogether, the more recent data from the questionnaire supports the following hypotheses: Even in the 21st century, the East Upper German language area can be distinguished as a contoured region from the use of geben 'give'-next to tun 'do'-as a (dialectal) basic verb for target-oriented object movements. Within the Bavarian language area, however, it is the Eastern parts in particular, in which the geben-variant is used frequently, whereas there is scarce evidence for this phenomenon in North Bavarian and (especially in Western) South Bavarian. The intergenerational comparison even reveals an areal expansion of the positioning verb geben 'give' over tun 'do'. This areal aggregation of geben 'give' as a PUT verb in German thus supports our language contact hypothesis.

\section{Summary}

This contribution is embedded at the intersection of variationist and contact linguistics. The phenomenon in focus is the verb geben 'give' in its function as a PUT verb in German and therefore in a language that according to the relevant research literature is currently classified as a PUT-less language. Our analyses provide evidence for the central hypothesis that the PUT semantics of German geben 'give' can be traced back to Czech-German language contact. A review of literature on language contact showed that from as early as (and basically only during) the 19th century hypotheses concerning the influence of Slavic languages on the spread of geben 'give' as a PUT verb had been suggested. In addition, our research on Slavic PUT verbs indicated that the use of GIVE verbs as basic PUT verbs is essentially a Central European phenomenon and possibly restricted to languages and varieties used in the area of the former Habsburg Empire. Contemporarily, this specific function of GIVE verbs appears to be more frequent in informal/colloquial varieties of these Slavic languages. At least in Czech, however, it has been part of the literary language since the 15 th century at latest.

Our paper is the first to provide thorough insight into the former and current distribution of geben 'give' as a PUT verb in the German-Czech contact area, especially at the border of Germany, Poland, Austria, and the Czech Republic. We facilitated this by analyzing and comparing two dialectological sources: on the one hand, results from an extensive questionnaire survey conducted between 1876 and 1933 that allowed for insights into the dialect situation of all the German-speaking areas in Europe of that time; on the other hand, results from a current survey on dialects conducted in 2010. The research results support the hypothesis that the use of geben 'give' as a PUT verb has spread from the language contact area of German (more specifically: Eastern Upper German) and Czech. Moreover, in this contact area, it is not only frequent to this day, but-against the background of intergenerational comparisons-also continues to spread.

The empirical focus of our contribution was limited to the dialect registers of German. However, as the examination of dictionaries on the German standard language showed, geben 'give' as a PUT verb can also be found in regiolectal ('intermediate') varieties of the dialectstandard axis and even in standard language contexts - at the least in Austria. Future research will also have to consider the diastratic variation of German geben 'give/put' and its potential spread across areas and varieties.

Acknowledgements. The authors thank Lena Katzinger for her help with translations as well as two anonymous reviewers for their useful comments. The research for this contribution was conducted in the framework of the SFB "German in Austria: Variation-Contact-Perception" (FWF 060), more specifically the project parts PP03 "Between dialects and standard varieties: Speech repertoires and varietal spectra" (FWF 060-03, principal investigator: Alexandra N. Lenz) and PP06 "German and the Slavic languages in Austria: Aspects of language contact" (FWF 060-06, principal investigator: Stefan Michael Newerkla), funded by the Austrian Science Fund (FWF). The authors are grateful for this support.

\section{Notes}

1 Following Fillmore (1982), the semantically defined categories (concepts) will be notated in small caps (e.g., GIVE or TAKE), and verbs or verb forms that refer to action concepts will be notated in italics (e.g., geben 'give', nehmen 'take').

2 On semantic networks of subject movements and their verbalization cf. e.g., Berthele (2011), Devos/van der Wal (2014). 
3 We cannot further elaborate on the complex semantic-conceptual relationship between HAVE and BE as well as on the general relationship of concepts such as POSSESSION, EXISTENCE and LOCATION. However, we want to refer to Bach (1967), Businger (2011), den Dikken (1997), Freeze (1992), Gronemeyer (1999), Heine (1997: esp. 50ff.), Jackendoff (1992: 60-67), Kayne (1993), Koch (1999), Lenz (2013), McIntyre (2005, 2006), and Wunderlich $(2006,2012)$. Interestingly enough, Heine (1997: 78) on the basis of a study of 100 world languages found that HAVE constructions can be attributed to "source schemata LOCATION and EXISTENCE" in more than $65 \%$ of all languages under analysis.

4 According to Rosch et al. (1976: 383) a category encompasses "a number of objects which are considered equivalent. Categories are generally designated by names, e.g., dog, animal. A taxonomy is a system by which categories are related to another by means of class inclusion. The greater the inclusiveness of a category within a taxonomy, the higher the level of abstraction. Each category within a taxonomy is entirely included within one other category (unless it is the highest-level category) but is not exhaustive of that more inclusive category $[\ldots]$. Thus, the term level of abstraction within a taxonomy refers to a particular level of inclusiveness."

5 Cf. Goldberg et al. (2003:196): "[ . . ] in the case of the VOL construction, (Subj) V Obj Obl $\mathrm{Oath}_{\text {/loc }}$, exemplified by the sentence, I put the book on the table. The verb put accounts for a full of 31 percent (16/51) of the instances of the construction, in the children's speech." Also Narasimhan et al. (2004:10): "[...] English put is typically described as a 'light verb' with relatively little meaning beyond its schematic sense of 'caused motion/change of location."

6 Cf. https://www.idee-fuer-mich.de/gesundheit/beschwerden-krankheiten/ sanfte-hilfe-aus-der-natur-wintermedizin-zum-selbermachen-3945: "Die Kanne mit der fertigen Lösung in den Kühlschrank stellen" ('Put the pot with the solution into the fridge').

7 Cf. https://www.zeit.de/2018/03/backwards-books-bibliotheken-umdrehen: "Aus Sentimentalität stellen sie das Buch umgedreht zurück ins Regal, [...]" ('Due to sentimentality they put the book back into the shelf reversely').

8 Cf. https://www.goldwing-forum.de/forum/topic.php?id=24629\&page=1\& $s=6583 b d 754591 c 0 b 533 f 0272 c 76 f 5 c d 35 \# 282893$ : “[ ...] lass Dir das Buch in den Koffer legen" ('[... ] let them put the book into the suitcase').

9 Cf. https://www.geschenke24.de/hochzeit/der-wandernde-hut/: "Zu Beginn des Spiels setzt sich ein Spieler einen Hut auf den Kopf" ('In the beginning of the game, one player puts a hat onto his head').

10 Cf. https://www.scootertuning.de/anfaengerfragen/474256-hilfe-auspuffpasst-mehr-dran.html: "Immer ein Tuch in das Loch stopfen [... ]" ('Always put some cloth into the hole [...]').

11 Cf. https://ef-magazin.de/2017/06/14/11167-gema-da-geht-das-messer-inder-tasche-auf: "Sie stecken das verrostete Taschenmesser in die Hosentasche" ('They put the rusty pocket knife into the trouser pocket').

12 Cf. https://www.merkur.de/leben/wohnen/badewanne-reinigen-natronbackpulver-waschpulver-essig-buttermilch-zr-10332777.html: "Mischen Sie kochendes Wasser und Apfelessig [...] und schütten Sie es ebenfalls in die Wanne hinein" ('Mix boiling water and cider vinegar [ ... ] and also put it into the tub').

13 Cf. https://www.beichthaus.com/?h=index\&search=Gie\%C3\%9Fen\&p= 20: "Jede Woche muss er [...] Fässer voll Wasser auf die Blumen gießen" ('Each week he has to pour barrels of water onto the flowers').

14 Throughout the whole paper, we will refer to the mentioned aspectual and reflexive forms by mentioning the non-reflexive, perfective infinitive dát $i$ 'give' only. Some constructions, however, require a certain form of the verb. In those cases, we highlight it accordingly.

15 In light of the taxonomy of motion acts depicted in Figure 1, we categorize acts of bringing and getting at the interface of subject movement and placement actions. Therefore, they are not prototypical PUT acts and we leave them aside in this context.

16 A numerical method is to be found in Fleischer (2011: 80).

17 The Czechoslovakian Wenker survey did exclusively cover the Germanspeaking parts of the country. Therefore, only 58 Czech Wenker questionnaires can be found in the complete corpus (cf. https://www.regionalsprache.de/ Wenkerbogen/Katalog.aspx; last access: 15 April 2019). None of them is included in sample I or sample II. The Czech questionnaires were collected in the original survey round and stem from the the Hlučín Region, which was part of the German Empire at that time. Nota bene: 34 out of these 58 questionnaires use dáti 'give' as a PUT verb in Wenker sentence \#3.

18 Other additional answers of older informants only provide phonetic variants for the provided stimuli. Such supposed alternatives suggest that the informants focused on the phonetic aspect rather than on the lexical aspect, which again confirms the research method and the validity of the results.

\section{References}

Ammon, Ulrich, Hans Bickel \& Alexandra N. Lenz (eds.). 2016. Variantenwörterbuch des Deutschen. Die deutsche Standardsprache in Austria, Switzerland, Germany, Liechtenstein, Luxembourg, Eastbelgium, South Tyrol and Rumania, Namibia and Mennonites'settlements. Berlin/ Boston: Walter de Gruyter.

Bach, Emmon. 1967. HAVE and BE in English syntax. Language 42(2). 462-485.

Berger, Tilman. 2009. Tschechisch-deutsche Sprachbeziehungen zwischen intensivem Kontakt und puristischer Gegenwehr. In Christel Stolz (eds.), Unsere sprachlichen Nachbarn in Europa. Die Kontaktbeziehungen zwischen Deutsch und seinen Grenznachbarn, 133-156. Bochum: Universitätsverlag Brockmeyer.

Berger, Tilman. 2014. The convergence of Czech and German between the years 900 and 1500. In Juliane Besters-Dilger, Cynthia Dermarkar, Stefan Pfänder \& Achim Rabus (eds.), Congruence in contact-induced language change: Language families, typological resemblance, and perceived similarity, 184198. Berlin: De Gruyter.

Berthele, Raphael. 2011. Ort und Weg: Die sprachliche Raumreferenz in Varietäten des Deutschen, Rätoromanischen und Französischen (Linguistik - Impulse \& Tendenzen, 16). Berlin: De Gruyter.

Berthele, Raphael. 2012. On the use of PUT verbs by multilingual speakers of Romansh. In Anetta Kopecka \& Bhuvana Narasimhan (eds.), Events of Putting and Taking: A crosslinguistic perspective, 146-165. Amsterdam: John Benjamins.

Berthele, Raphael. 2014. Variation, Konsens und Konvergenz. Sprechen über Raum im Kontext von Mehrsprachigkeit. In Irene Doval \& Barbara Lübke (eds.), Raumlinguistik und Sprachkontakt. Neue Beiträge zu spatialen Relationen im Deutschen, Englischen und Spanischen, 15-45. München: iudicium.

Blatná, Renata, František Čermák, Jaroslava Hlaváčová, Milena Hnátková, Jan Kocek, Marie Kopřivová, Michal Křen, Karel Kučera, Vladimír Petkevič, Věra Schmiedtová, Martin Stluka \& Michal Šulc. 2004. Frekvenční slovník češtiny. Praha: Nakladatelství Lidové noviny.

Businger, Martin. 2011. «Haben` als Vollverb. Eine dekompositionelle Analyse (Linguistische Arbeiten 538). Berlin: De Gruyter.

Čermák, František \& Alexandr Rosen. 2012. The case of InterCorp, a multilingual parallel corpus. International Journal of Corpus Linguistics 17(3). 411-427.

Cornwall, Mark. 1994. The struggle on the Czech-German language border 1880-1940. The English Historical Review CXI (433). 914-951.

den Dikken, Marcel. 1997. The syntax of possession and the verb 'have'. Lingua 101. 129-150.

Devos, Maud \& Jenneke van der Wal (eds.). 2014. COME and GO off the beaten grammaticalization path (Trends in Linguistics. Studies and Monographs 272). Berlin: De Gruyter.

Fagan, Sarah. 1991. The semantics of the positional predicates liegen/legen, sitzen/setzen, and stehen/stellen. Die Unterrichtspraxis 24. 136-145.

Filipec, Josef, František Daneš, Jaroslav Machač, Vladimír Mejstř́ik (eds.). 1994. Slovník spisovné češtiny pro školu a veřejnost. 2. vydání [SSČ]. Praha: Academia.

Fillmore, Charles. 1982. Frame semantics. In The Linguistic Society of Korea (ed.), Linguistics in the morning calm, 111-137. Seoul: Hanshin Publ.

Fleischer, Jürg. 2011. ... und habe es ihr gesagt. Zur dialektalen Abfolge pronominaler Objekte (eine Auswertung von Wenkersatz 9). In Elvira Glaser, Jürgen Erich Schmidt \& Natascha Frey (eds.), Dynamik des Dialekts. Wandel und Variation. Akten des 3. Kongresses der Internationalen Gesellschaft für Dialektologie des Deutschen (IGDD) (Zeitschrift für Dialektologie und Linguistik. Beihefte 144), 77-100. Stuttgart: Steiner.

Fleischer, Jürg. 2015. Pro-Drop und Pronominalenklise in den Dialekten des Deutschen: eine Auswertung von Wenkersatz 12. In Michael Elmentaler, 
Markus Hundt \& Jürgen Erich Schmidt (eds.), Deutsche Dialekte: Konzepte, Probleme, Handlungsfelder. Akten des 4. Kongresses der Internationalen Gesellschaft für Dialektologie des Deutschen (IGDD) (Zeitschrift für Dialektologie und Linguistik. Beihefte 158), 191-209, 504-505 [maps]. Stuttgart: Steiner.

Fleischer, Jürg. 2017. Geschichte, Anlage und Durchführung der FragebogenErhebungen von Georg Wenkers 40 Sätzen: Dokumentation, Entdeckungen und Neubewertungen. Hildesheim et al.: Georg Olms.

Freeze, Ray. 1992. Existentials and other locatives. Language 68. 553-595.

Fuková, Irena et al. (eds.). 2006-. Elektronický slovník staré češtiny (online) [ESSČ]. Accessible online: https://vokabular.ujc.cas.cz/hledani.aspx (4 September 2019).

Georges, Karl Ernst. 1913. Ausführliches lateinisch-deutsches Handwörterbuch, aus den Quellen zusammengetragen und mit besonderer Bezugnahme auf Synonymik und Antiquitäten unter Berücksichtigung der besten Hilfsmittel ausgearbeitet. Vol. 1. Hannover: Hahnsche Buchhandlung.

Glaser, Elvira. 2008. Syntaktische Raumbilder. In Peter Ernst \& Franz Patocka (eds.), Dialektgeographie der Zukunft. Akten des 2. Kongresses der Internationalen Gesellschaft für Dialektologie des Deutschen (IGDD) (Zeitschrift für Dialektologie und Linguistik. Beihefte 135), 85-111. Stuttgart: Steiner.

Goldberg, Adele. 1995. Constructions: A construction grammar approach to argument structure. Chicago: University of Chicago Press.

Goldberg, Adele, Devin Casenhiser \& Nitya Sethuraman. 2003. A lexically based proposal of argument structure meaning. Proceedings from the Annual Meeting of the Chicago Linguistic Society 39(2). 67-81.

Gronemeyer, Claire. 1999. On deriving complex polysemy. The grammaticalization of get. English Language and Linguistics 3(1). 1-39.

Hauptová, Zoe, Marija Klenovar \& Ivana Mulc (eds.). 2008. Rječnik crkvenoslavenskoga jezika hrvatske redakcije. 15. danv-dovolně. Zagreb: Staroslavenski institut.

Havránek, Bohuslav, Jaromír Bělič, Miloš Helcl, Alois Jedlička, Václav Kř́istek \& František Trávníček (eds.). 1960-1971. Slovník spisovného jazyka českého. První vydání [SSJČ]. 8 vol. Praha: Státní pedagogické nakladatelství.

Heine, Bernd. 1997. Possession: Sources, forces, and grammaticalization (Cambridge Studies in Linguistics 83). Cambridge: Cambridge University Press.

Heine, Bernd \& Tania Kuteva. 2002. World Lexicon of Grammaticalization. Cambridge: Cambridge University Press.

Hujer, Oldřich, Emil Smetánka, Miloš Weingart, Bohuslav Havránek, Vladimír Šmilauer \& Alois Získal (eds). 1935-1957. Přiruční slovník jazyka českého [PSJČ]. 9 vol. Praha: Státní pedagogické nakladatelství.

Ivanova-Mirčeva, Dora, Angel Davidov \& Živka Ikonomova (eds.). 1999. Starobălgarski rečnik. Vol. 1. a-n. Sofia: Izdatelstvo Valentin Trajanov.

Jackendoff, Ray. 1992. Languages of the mind: Essays on mental representation. Cambridge, London: MIT Press.

Jones, Randall \& Erwin Tschirner. 2006. A frequency dictionary of German. Core vocabulary for Learners. London: Routledge.

Kayne, Richard. 1993. Toward a modular theory of auxiliary selection. Studia Linguistica 47(1). 3-31.

Kim, Agnes. 2018a. InterCorp - Ein mehrsprachiges Parallelkorpus des Tschechischen Nationalkorpus (Český národní korpus). RIDE 9. DOI: https://ride.i-d-e.de/issues/issue-9/intercorp/.

Kim, Agnes. 2018b. Von „rein deutschen“ Orten und „tschechischen Minderheiten“. Spracheinstellungen und bevölkerungspolitisches Bewusstsein in den Wenkerbögen. In Hannes Philipp, Andrea Ströbl, Bernadette Weber \& Johann Wellner (eds.), Deutsch in Mittel- Ost und Südosteuropa. DiMOS-Füllhorn Nr. 3, 275-318. Regensburg: Open Access Schriftenreihe der Universitätsbibliothek Regensburg. DOI: 10.5283/epub. 37387.

Kim, Agnes. 2019. Multilingual Lower Austria: Historical sociolinguistic investigations on Wenker's questionnaires. In Lars Bülow, Kristina Herbert \& Ann-Kathrin Fischer (eds.), Dimensionen des sprachlichen Raumes. Variation - Mehrsprachigkeit - Konzeptualisierung, 187-211. Frankfurt am Main et. al.: Peter Lang.

Kim, Agnes \& Katharina Prochazka. 2019. Slawisch und Deutsch in Österreich. Methodische Ansätze zur Rekonstruktion historischen Sprachkontakts und seiner Einflüsse auf das Deutsche in Österreich. Wiener Slavistisches Jahrbuch N. F. 7. 1-27.

Koch, Peter. 1999. Cognitive aspects of semantic change and polysemy: The semantic space HAVE/BE. In Andreas Blan \& Peter Koch (eds.), Historical semantics and cognition (Cognitive Linguistics Research 13), 279-306. New York: De Gruyter.

Kopecka, Anetta. 2012. Semantic granularity of placement and removal expressions in Polish. In Anetta Kopecka \& Bhuvana Narasimhan (eds.), Events of Putting and Taking. A crosslinguistic perspective, 328-347. Amsterdam: John Benjamins.

Kurz, Josef, Antonín Dostál \& Markéta Štěrbová (eds.). 1958. Slovník jazyka staroslověnského. Vol. I. a-đ. Praha: Academia.

Leisi, Ernst. 1961. Der Wortinhalt. Seine Struktur im Deutschen und Englischen. Zweite, erweiterte Auflage. Heidelberg: Quelle \& Meyer.

Lenz, Alexandra. 2013. Three "competing" auxiliaries of a non-canonical passive. On the German GET passive and its auxiliaries. In Artemis Alexiadou \& Florian Schäfer (eds.), Non-Canonical Passives (Linguistik Aktuell/ Linguistics Today 205), 64-94. Amsterdam: John Benjamins.

Lenz, Alexandra. 2017. GIVE- und GET-Passive im Deutschen und Luxemburgischen. Von der Affinität transferentieller Verben zur PassivAuxiliarisierung. In Sprachwissenschaft 43/2 (special issue „Aktuelle Ansichten zur Synchronie und Diachronie von Passivkonstruktionen"), 187-219.

Lenz, Alexandra, Timo Ahlers \& Martina Werner. 2015. Zur Dynamik bairischer Dialektsyntax Eine Pilotstudie. Zeitschrift für Dialektologie und Linguistik LXXXI/1. 1-33.

Lopatková, Markéta, Václava Kettnerová, Eduard Bejček, Anna Vernerová \& Zdeněk Žabokrtský. 2016. Valenční slovník českých sloves VALLEX. Praha: Karolinum.

McIntyre, Andrew. 2005. The semantic and syntactic decomposition of get: An interaction between verb meaning and particle placement. Journal of Semantics 22(4). 401-438.

McIntyre, Andrew. 2006. The interpretation of German datives and English have. In Daniel Hole, André Meinunger \& Werner Abraham (eds.), Datives and Other Cases. Amsterdam: Benjamins. 185-211.

Muysken, Pieter. 2010. Scenarios for Language Contact. In Raymond Hickey (eds.), The Handbook of Language Contact, 265-281. Chichester: WileyBlackwell.

Muysken, Pieter. 2013. Language contact outcomes as the result of bilingual optimization strategies. Bilingualism: Language and Cognition 16(4). 709-730.

Narasimhan, Bhuvana, Melissa Bowerman, Marianne Gullberg \& Asifa Majid. 2004. Put project: The cross-linguistic encoding of placement events. Field Manual 9. 10-24.

Narasimhan, Bhuvana, Anetta Kopecka, Melissa Bowerman, Marianne Gullberg \& Asifa Majid. 2012. Putting and taking events: A crosslinguistic perspective. In Anetta Kopecka \& Bhuvana Narasimhan (eds.), Events of Putting and Taking. A crosslinguistic perspective (Typological Studies in Language 100). 1-2. Philadelphia: John Benjamins.

Nekula, Marek \& Radoslav Večerka. 2017. Bohemismus. In Petr Karlík, Marek Nekula, Jana Pleskalová (eds.) \& Autorenkollektiv, Nový encyklopedicky slovník češtiny. a-m, 172-179. Praha: Nakladatelství Lidové noviny. Accessible online in CzechEncy - NESČ: https://www.czechency.org/ slovnik/BOHEMISMUS

Newerkla, Stefan Michael. 2002. Sprachliche Konvergenzprozesse in Mitteleuropa. In Ivo Pospíšil (ed.), Crossroads of Cultures: Central Europe (Litteraria Humanitas XI), 211-236. Brno: Masarykova univerzita.

Newerkla, Stefan Michael. 2007a. Areály jazykového kontaktu ve střední Evropě a německo-český mikroareál ve východním Rakousku. Slovo a slovesnost 68(4). 271-286.

Newerkla, Stefan Michael. 2007b. Kontaktareale in Mitteleuropa. In Andrzej Kątny (eds.), Stowiańsko-niesłowiańskie kontakty językowe. Slawisch-nichtslawische Sprachkontakte, 29-48. Olecko: Wszechnica Mazurska.

Newerkla, Stefan Michael. 2011. Sprachkontakte Deutsch - Tschechisch Slowakisch. Wörterbuch der deutschen Lehnwörter im Tschechischen und Slowakischen: historische Entwicklung, Beleglage, bisherige und neue Deutungen. Zweite, durchgehend überarbeitete und aktualisierte Auflage (Schriften über Sprachen und Texte 7). Frankfurt am Main et al.: Peter 
Lang. DOI: http://dx.doi.org/10.3726/978-3-653-03121-8 (Open Access CCBY-NC 4.0).

Newerkla, Stefan Michael. 2017. Germanismy v českém lexiku. In Petr Karlík, Marek Nekula, Jana Pleskalová (eds.) \& Autorenkollektiv, Nový encyklopedický slovník češtiny. a-m, 584-588. Praha: Nakladatelství Lidové noviny. Accessible online in CzechEncy - NESČ: https://www.czechency. org/slovnik/GERMANISMY\%20V\%20\%C4\%8CESK\%C3\%89M\%20LEXIKU

Newman, John. 1996. Give. A Cognitive Linguistic Study (Cognitive Linguistics Research 7). New York: De Gruyter.

Newman, John. 2005. Three-place predicates: A cognitive-linguistic perspective. Language Sciences 27. 145-163.

Rosch, Eleanor, Carolyn B. Mervis, Wayne D. Gray, David M. Johnson \& Penny Boyes-Braem. 1976. Basic objects in natural categories. Cognitive Psychology 8. 382-439.

Rosen, Alexandr. 2012. InterCorp - a look behind the façade of a parallel corpus. In Ewa Gruszczyńska \& Agnieszka Leńko-Szymańska, Polskojęzyczne korpusy równoległe. Polish-language Parallel Corpora, 21-40. Warszawa: Instytut Lingwistyki Stosowanej.

Rosen, Alexandr \& Martin Vavř́n. 2012. Building a multilingual parallel corpus for human users. In Nicoletta Calzolari, Khalid Choukri, Thierry Declerck, Mehmet Uğur Doğan, Bente Maegaard, Joseph Mariani, Asuncion Moreno, Jan Odijk \& Stelios Piperidis (eds.), Proceedings of the Eight International Conference on Language Resources and Evaluation (LREC 2012), 24472452. Istanbul: European Language Resources Association (ELRA).

Rosen, Alexandr \& Martin Vavř́n. 2016. Korpus InterCorp. Version 9 from 9.9.2016. Praha: Ústav Českého národního korpusu, FF UK. Accessible online: https://www.korpus.cz/.

Ryba, Bohumil \& Jan Martínek (eds.). 1992. Latinitatis medii aevi lexicon Bohemorum. Vol. 2. D-H. Praha: Kabinet pro Klasická Studia. Accessible online: http://lb.ics.cas.cz/.

Schleicher, August. 1851. Über die wechselseitige Einwirkung von Böhmisch und Deutsch. Archiv für das Studium der neueren Sprachen und Literaturen 9. 38-42.

Schmidt, Jürgen Erich \& Joachim Herrgen. 2011. Sprachdynamik. Eine Einführung in die moderne Regionalsprachenforschung (Grundlagen der Germanistik 49). Berlin: Erich Schmidt.
Scholze-Stubenrecht, Werner (ed.). 2015. Duden. Deutsches Universalwörterbuch. Achte, überarbeitete und erweiterte Auflage. Berlin: Dudenverlag.

Schuchardt, Hugo. 1884. Slawo-Deutsches und Slawo-Italienisches. Dem Herrn Franz von Miklosich zum 20.11.1883. Graz: Leuschner und Lubensky.

Skála, Emil. 1964. Die Entwicklung des Bilinguismus in der Tschechoslowakei vom 13. bis 18. Jahrhundert. Beiträge zur Geschichte der deutschen Sprache und Literatur LXXXVI. 69-106.

Škrabal, Michal \& Martin Vavř́n. 2017. Databáze překladových ekvivalentů Treq. Časopis pro moderní filologii 99(2). 245-260.

Teweles, Heinrich. 1884. Der Kampf um die Sprache. Linguistische Plaudereien. Leipzig: Carl Meißner.

Ústav pro jazyk český AV ČR, v. v. i., oddělení vývoje jazyka (eds.). n.y. Staročeská textová banka. Version 1.1.4. Accessible online: http:// vokabular.ujc.cas.cz/banka.aspx?idz=STB (09 April 2019).

Weinreich, Uriel. 1979 [1953]. Languages in contact. Findings and problems. Ninth Print. De Hague: Mouton.

Wiesinger, Peter. 1983. Die Einteilung der deutschen Dialekte. In Werner Besch, Ulrich Knoop, Wolfgang Putschke, Herbert Ernst Wiegand (eds.), Dialektologie. Ein Handbuch zur deutschen und allgemeinen Dialektforschung. 2. Halbbd. 807-900. Berlin: de Gruyter.

Wunderlich, Dieter. 2006. Towards a structural typology of verb classes. In id. (ed.), Advances in the Theory of the Lexicon. New York: De Gruyter. 57-166.

Wunderlich, Dieter. 2012. Lexical decomposition in grammar. In Markus Werning, Wolfram Hinzen \& Edouard Machery (eds.), The Oxford Handbook of Compositionality (Oxford Handbooks in Linguistics), 307-327. Oxford: Oxford University Press.

Žaža, Stanislav. 2001. K funkci slovesa dát - damb v češtině a v ruštině. In Ondřej Šefč́k \& Bohumil Vykypěl (ed.), Grammaticus. Studia linguistica Adolfo Erharto quinque et septuangenario oblata, 226-232. Brno: MU.

Žaža, Stanislav. 2006. Сходства и различия в значении и употреблении глаголов дать - dát, даться - dát se в русском и чешском языках. Przegląd Rusycystyczny 115, 125-131. 